\title{
Observations of rapid aerosol optical depth enhancements in the vicinity of polluted cumulus clouds
}

\author{
T. F. Eck ${ }^{1,2}$, B. N. Holben ${ }^{2}$, J. S. Reid ${ }^{3}$, A. Arola ${ }^{4}$, R. A. Ferrare ${ }^{5}$, C. A. Hostetler ${ }^{5}$, S. N. Crumeyrolle ${ }^{5,6}$, \\ T. A. Berkoff ${ }^{7,5}$, E. J. Welton ${ }^{2}$, S. Lolli ${ }^{2,7}$, A. Lyapustin ${ }^{2}$, Y. Wang ${ }^{2,7}$, J. S. Schafer ${ }^{2,8}$, D. M. Giles ${ }^{2,8}$, B. E. Anderson ${ }^{5}$, \\ K. L. Thornhill ${ }^{5,9}$, P. Minnis ${ }^{5}$, K. E. Pickering ${ }^{2}$, C. P. Loughner ${ }^{2,10}$, A. Smirnov ${ }^{2,8}$, and A. Sinyuk ${ }^{2,8}$ \\ ${ }^{1}$ Universities Space Research Association, GESTAR, Columbia, MD, USA \\ ${ }^{2}$ NASA, GSFC, Greenbelt, MD, USA \\ ${ }^{3}$ Naval Research Laboratory, Monterey, CA, USA \\ ${ }^{4}$ Finnish Meteorological Institute, Kuopio, Finland \\ ${ }^{5}$ NASA LRC, Hampton, VA, USA \\ ${ }^{6}$ LOA, UMR8518, CNRS - Université Lille1, Villeneuve d'Ascq, France \\ ${ }^{7}$ University of Maryland Baltimore County, JCET, Baltimore, MD, USA \\ ${ }^{8}$ Sigma Space Corporation, Lanham, MD, USA \\ ${ }^{9}$ Science Systems and Applications, Inc., Lanham, MD, USA \\ ${ }^{10}$ University of Maryland, ESSIC, College Park, MD, USA
}

Correspondence to: T. F. Eck (thomas.f.eck@nasa.gov)

Received: 6 May 2014 - Published in Atmos. Chem. Phys. Discuss.: 17 July 2014

Revised: 16 September 2014 - Accepted: 23 September 2014 - Published: 6 November 2014

\begin{abstract}
During the July 2011 Deriving Information on Surface conditions from Column and Vertically Resolved Observations Relevant to Air Quality (DISCOVER-AQ) field experiment in Maryland, significant enhancements in Aerosol Robotic Network (AERONET) sun-sky radiometer measured aerosol optical depth (AOD) were observed in the immediate vicinity of non-precipitating cumulus clouds on some days. Both measured Ångström exponents and aerosol size distribution retrievals made before, during and after cumulus development often suggest little change in fine mode particle size; therefore, implying possible new particle formation in addition to cloud processing and humidification of existing particles. In addition to sun-sky radiometer measurements of large enhancements of fine mode AOD, lidar measurements made from both ground-based and aircraftbased instruments during the experiment also measured large increases in aerosol signal at altitudes associated with the presence of fair weather cumulus clouds. These data show modifications of the aerosol vertical profile as a result of the aerosol enhancements at and below cloud altitudes. The airborne lidar data were utilized to estimate the spatial extent of these aerosol enhancements, finding increased AOD,
\end{abstract}

backscatter and extinction out to $2.5 \mathrm{~km}$ distance from the cloud edge. Furthermore, in situ measurements made from aircraft vertical profiles over an AERONET site during the experiment also showed large increases in aerosol scattering and aerosol volume after cloud formation as compared to before. The 15-year AERONET database of AOD measurements at the Goddard Space Flight Center (GSFC), Maryland site, was investigated in order to obtain a climatological perspective of this phenomenon of AOD enhancement. Analysis of the diurnal cycle of AOD in summer showed significant increases in AOD from morning to late afternoon, corresponding to the diurnal cycle of cumulus development.

\section{Introduction}

One of the more difficult issues concerning the analysis and remote sensing of the forcing agents of climate change is the monitoring of interactions between clouds and aerosol particles. While there is no dispute that clouds significantly affect the aerosol environment around them, passive satellite retrievals of AOD are more likely biased towards co-varying 
cloud contamination or illumination bias than physical processes (e.g., Ignatov et al., 2005; Zhang et al., 2005; Zhang and Reid, 2006; Marshak et al., 2008; Smirnov et al., 2012; Reid et al., 2013). Thus, a significant challenge to the climate science community is to link remote-sensing measurements of potential changes in aerosol optical depth (AOD) to Cloud Condensation Nuclei Concentration (e.g., Kaufman and Fraser, 1997) or to secondary particle production, free of retrieval artifacts. Indeed, if the community's wish to perform comprehensive top-down inventories of aerosol particle production is to be fulfilled, high frequency observations and inverse modeling of the aerosol environment around clouds will be required. However, as previously stated passive remote sensing in the vicinity of clouds is problematic. Therefore, non-lidar remote-sensing data sets from satellites are typically biased towards measurements made away from the immediate vicinity or edges of clouds, in addition to typically having little aerosol information when cloud fraction is very high. This bias towards low cloud fraction meteorological conditions also applies to ground-based remote-sensing observations such as from sun-sky radiometers, although to a lesser extent than from satellite. A fundamental question is then the following: how accurately can the relative signal of aerosol production and growth/humidification around clouds be observed?

The aerosol environment around clouds is well recognized to be complex. One must consider larger-scale air-mass changes associated with cloud fields as well as the potential for large-scale secondary particle production. The relationships between cloud cover and column particle load can be a result of a buildup in boundary layer aerosol particle concentrations from cloud processing, or simply meteorological transport covariance. Many investigations have found evidence of higher aerosol concentrations in the immediate vicinity of cumulus clouds, forming so called halos. These halos are in part a combination of detrained aerosol particles from cloud base, higher humidity, and hence hygroscopic growth and production of secondary aerosol particle mass. For example, Radke and Hobbs (1991) from in situ aircraftbased measurements found aerosol concentrations that were twice as high in the near-cloud environment of small cumulus (at 200-300 $\mathrm{m}$ above cloud bases) as those far from the clouds, and these near-cloud regions also had high relative humidity and high turbulence.

The dominant and rapid oxidation pathways for sulfate, nitrate and organics in clouds has been long recognized by the community. Lelieveld and Heintzenberg (1992) suggested that sulfate production in clouds by oxidation within cloud droplets is the dominant factor governing sulfate concentrations, and they estimated that sulfate under goes multiple (3 to 7) condensation-evaporation events within clouds in a typical one week lifetime. Lu et al. (2003) observed enhanced relative humidity halos $(\mathrm{RH})$ around marine trade wind cumulus and also found evidence of particle formation and/or modification in the halo region. These reactions are thought to be very fast when conditions are favorable. In laboratory chamber produced clouds, Hansen et al. (1991) found that up to $80 \%$ of $\mathrm{SO}_{2}$ was oxidized to sulfate within minutes or less when in the presence of ammonia, while no sulfate was produced when all water was in the vapor phase. Loughner et al. (2011) simulated the conversion of $\mathrm{SO}_{2}$ to sulfate for a summer fair weather cumulus cloud environment in the Washington, D.C.-Baltimore region. They found that realistic spatial simulations of cumulus clouds that produced the most clouds subsequently transported more $\mathrm{SO}_{2}$ aloft and produced the best agreement with measured sulfate and $\mathrm{SO}_{2}$ concentrations. Similarly for nitrate, Hayden et al. (2008) found through both in situ measurements and modeling that the production of nitrate aerosol occurs during aqueous-phase reactions within cumulus clouds. They found that the size of the resultant cloud processed or residual nitrate particles were smaller than sulfate particles formed in the same clouds. Additionally, the modeling studies of Shrivastava et al. (2013) found significant residual nitrate aerosol production associated with cumulus clouds, which were consistent with observations made near Oklahoma City during the Cumulus Humilis Aerosol Processing Study (CHAPS). Finally, in a review of secondary organic aerosol (SOA) measurement and modeling studies, Ervens et al. (2011) determined that SOA formation in the aqueous phase (in both cloud droplets and aerosol water) is significant, possibly contributing as much mass to total SOA as particles formed in the gaseous phase.

Sun photometers monitor the regional ambient aerosol state of the total integrated atmospheric column. There is no adjacency effect in sun photometer data when measurements of AOD are made in close proximity to clouds, and the much higher effective spatial and temporal resolution, such as from instruments in the Aerosol Robotic Network (AERONET), allows for much less potential cloud contamination. The spectral deconvolution method (O'Neill et al., 2003), which separates fine and coarse mode AOD, further isolates potential cloud effects. Zhang et al. (2005) and Jeong and $\mathrm{Li}$ (2010) examined satellite and sun photometer derived AODs for marine and continental clouds, respectively. The findings of Zhang et al. (2005) suggest that $70 \%$ of the increased satellite signal in AOD in the vicinity of clouds is due to cloud contamination, with the remaining $30 \%$ due to hygroscopicity or secondary production. For clouds in Oklahoma, Jeong and Li (2010) found, from both sun photometer and in situ data, enhanced AOD near clouds and that only $\sim 25 \%$ of the enhancement was due to humidification, while most was due to the combined effects of new particle formation, cloud processing of particles and convergence of air in clouds. Eck et al. (2012) presented evidence of aerosol growth through cloud processing after the evaporation of extensive fog or low altitude stratus (layer) clouds, with retrieved size distributions from AERONET showing bimodality similar to that measured by various in situ field measurements. 
To add vertical resolution to aerosol monitoring, active remote sensing of aerosol from lidar measurements does not have the issue of cloud adjacency effects that passive satellite measurements do, and the screening of cloud contamination is also significantly more robust from lidar data. Tackett and Girolamo (2009), Várnai and Marshak (2011) and Yang et al. (2012) have all analyzed Cloud-Aerosol Lidar and Infrared Pathfinder Satellite Observations (CALIPSO) lidar data over oceans to investigate the relationship between aerosol signal and clouds. Yang et al. (2012) analyzed the highest confidence CALIPSO space-based lidar data to investigate the relationship between aerosol signal (backscatter) and distance from clouds and also the size of clouds. They found that the aerosol signal has a sharp increase within $4 \mathrm{~km}$ of clouds with the color ratio suggesting larger particles near clouds, and also that the aerosol backscatter increase is greater for larger size (horizontal dimension) clouds, possibly since larger clouds often have a greater vertical extent and can affect a deeper layer of the atmosphere. Su et al. (2008) utilized high-spectral-resolution lidar (HSRL) observations made from aircraft to study the aerosol in close proximity to clouds for flights made in August in the mid-Atlantic and Southeastern United States region. They found AOD enhancements in the vicinity of clouds, with AOD at $532 \mathrm{~nm}$ that were $8-17 \%$ higher at $100 \mathrm{~m}$ from clouds as compared to $4.5 \mathrm{~km}$ distance from clouds, with no systematic change in lidar ratio observed implying little change in particle size and absorption.

During July 2011 an extensive field experiment provided an ideal opportunity to investigate remote-sensing signals of air pollutants. In the current paper we analyze the AERONET measurements of AOD in the proximity of fair weather (nonprecipitating) cumulus clouds during this field campaign. We also analyze coincident in situ measurements from aircraft of aerosol both before and after non-precipitating cumulus cloud formation, and additionally both ground-based and airborne lidar measurements to observe the aerosol optical effects both temporally and spatially in the near environment of fair weather cumulus clouds. Finally, we examine the AOD climatology at the GSFC, Maryland site, to analyze the possible influence of cumulus clouds on the diurnal cycle of AOD.

\section{Instrumentation and methodology}

\subsection{DISCOVER-AQ Maryland campaign and associated DRAGON network}

The field experiment titled Deriving Information on Surface conditions from Column and Vertically Resolved Observations Relevant to Air Quality (DISCOVER-AQ) in Maryland was conducted during the month of July 2011. Repeated instrumented aircraft flights including transects and vertical profiles were flown on 14 days in this month in order to make in situ aerosol and gas measurements and also downward

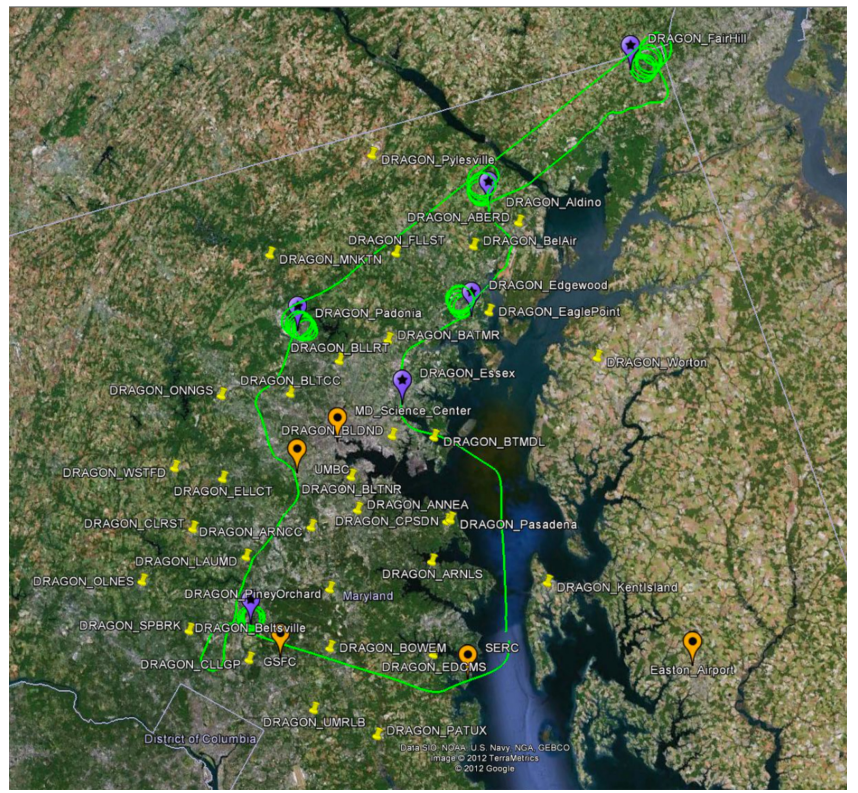

Figure 1. The DISCOVER-AQ Maryland July 2011 field experiment region is shown. The yellow, orange and purple markers denote the location of AERONET sun-sky radiometer sites, mostly as DRAGON field campaign deployments. A typical flight circuit of the NASA P3-B aircraft is depicted in green with spiral profiles made over principal ground-instrumented sites.

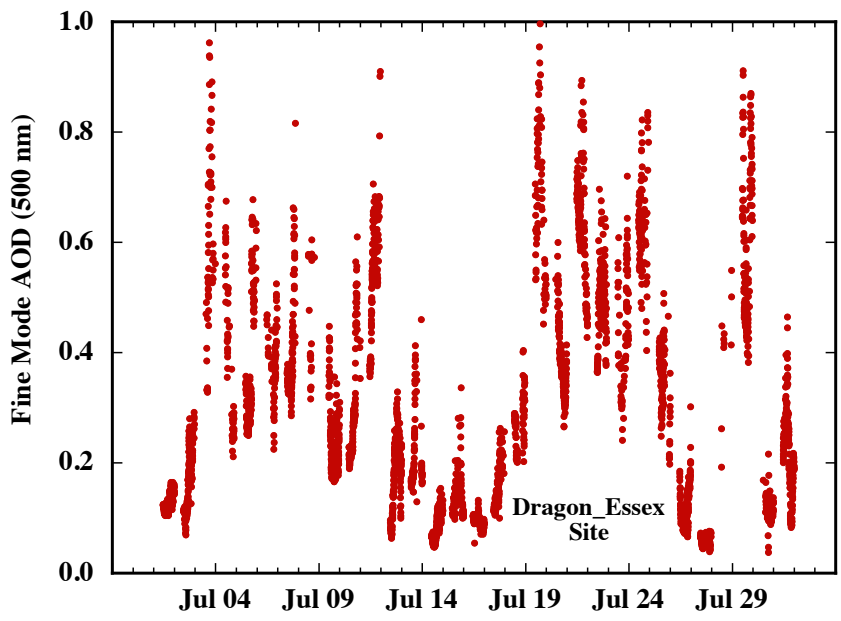

Figure 2. Fine mode AOD at $500 \mathrm{~nm}$ determined from the spectral deconvolution algorithm (SDA) utilizing measured direct sun AOD spectra from 380 to $870 \mathrm{~nm}$ as input, from all measurements taken at the DRAGON_Essex site (near Baltimore) during July 2011. These data have not been screened for clouds (Level 1 data), since SDA identifies cloud optical depth as coarse mode AOD. Instantaneous fine mode $500 \mathrm{~nm}$ AOD ranged from 0.04 to 1.00 over the entire month. Note that this Level 1 AOD data does have final calibrations applied, however, as does all Level 1 data analyzed in this study. 
viewing lidar measurements (see Sects. 2.5 and 2.6 below). AERONET deployed over 40 Cimel sun-sky radiometers in a meso-scale Distributed Regional Aerosol Gridded Observation Network (DRAGON) in Maryland from north of Washington, D.C. to nearly the Delaware border in support of the DISCOVER-AQ field campaign in July 2011 (Fig. 1). In Fig. 2 we present the fine mode AOD retrievals derived from measurements made at a representative AERONET site (DRAGON_Essex) for the entire month of the campaign. Based on the assumption that aerosol size distributions are bimodal, O'Neill et al. $(2001,2003)$ developed the spectral deconvolution algorithm (SDA) that utilizes spectral total extinction AOD data to infer the component fine and coarse mode optical depths. An additional fundamental assumption of the algorithm is that the coarse mode Ångström exponent and its derivative are both close to zero. The Ångström exponent $\alpha$ and the spectral variation of $\alpha$ (as parameterized by $\alpha^{\prime}=\mathrm{d} \alpha / \mathrm{d} \ln \lambda$ ) are the measurement inputs to the SDA. These continuous-function derivatives (computed here at a reference wavelength of $500 \mathrm{~nm}$ ) are derived from a second order fit of $\ln$ AOD vs. $\ln \lambda$ (Eck et al., 1999). The measured spectral AODs employed as input to the SDA were limited to the five Cimel wavelengths ranging from 380 to $870 \mathrm{~nm}$. The AERONET data in Fig. 2 were not screened for clouds (Level 1; see Sect. 2.2 below), since O'Neill et al. (2003) have shown that SDA identifies cloud optical depth as the coarse mode AOD component. Analysis by Chew et al. (2011) of AERONET measured spectral AOD in conjunction with lidar data in Singapore has shown that the SDA technique effectively separated the coarse mode (cirrus cloud contamination, as identified by lidar) from the total optical depth without affecting the fine mode component. Additionally, Kaku et al. (2014) have verified that the SDA technique is also effective in separating the fine and coarse modes from in situ spectral optical measurements. During the DISCOVER-AQ campaign, the fine mode AOD derived from SDA exhibited a very wide range of values during this month at the DRAGON_Essex site, from 0.04 to 1.00 (Fig. 2), with measurements made every day of the month.

\subsection{AERONET instrumentation}

The Cimel Electronique CE-318 sun-sky radiometer measurements were made with instruments that are a part of the Aerosol Robotic Network (AERONET) global network. These instruments are described in detail by Holben et al. (1998); however, a brief description is given here. The automatic tracking sun and sky scanning radiometers made direct sun measurements with a $1.2^{\circ}$ full field of view every $15 \mathrm{~min}$ at $340,380,440,500,675,870,940$ and $1020 \mathrm{~nm}$ (nominal wavelengths; includes the $1640 \mathrm{~nm}$ channel in extended wavelength Cimel versions). The direct sun measurements take $\sim 8 \mathrm{~s}$ to scan all wavelengths (repeated three times within a minute), with a motor driven filter wheel positioning each filter in front of the detector. These solar extinc- tion measurements are used to compute aerosol optical depth (AOD) at each wavelength except for the $940 \mathrm{~nm}$ channel, which is used to retrieve total column water vapor (or precipitable water) in centimeters. The filters utilized in these instruments were ion assisted deposition interference filters with bandpass (full width at half maximum) of $10 \mathrm{~nm}$, except for the 340 and $380 \mathrm{~nm}$ channels at $2 \mathrm{~nm}$. The estimated uncertainty in computed AOD, due primarily to calibration uncertainty, is $\sim 0.010-0.021$ for field instruments (which is spectrally dependent with the higher errors in the UV; Eck et al., 1999). Schmid et al. (1999) compared AOD values derived from 4 different solar radiometers (including an AERONET sun-sky radiometer) operating simultaneously together in a field experiment and found that the AOD values from 380 to $1020 \mathrm{~nm}$ agreed to within 0.015 (root mean square), which is similar to our estimated level of uncertainty in AOD measurements for field instruments. For some of the analyses presented, the spectral aerosol optical depth data have been screened for clouds following the methodology of Smirnov et al. (2000), which relies on the higher temporal frequencies of cloud optical depth vs. aerosol optical depth, especially optical depth triplet variability within one minute. Triplet variability is defined as the maximum minus minimum AOD of the three values taken in a one-minute time interval for each wavelength, with all spectral channels being checked for triplet range. AOD measurements pass the Version 2 cloud screening when triplet variability is less than either 0.02 or 0.03 AOD (whichever value is higher). The sky radiances measured by the sun-sky radiometers are calibrated vs. frequently characterized integrating spheres at the NASA Goddard Space Flight Center (GSFC), to an absolute accuracy of $\sim 5 \%$ or better (Holben et al., 1998).

\subsection{AERONET inversion methodology}

The Cimel sky radiance measurements in the almucantar geometry (fixed elevation angle equal to solar elevation and $\pm 180^{\circ}$ azimuthal sweeps) at $440,675,870$ and $1020 \mathrm{~nm}$ (nominal wavelengths) in conjunction with the direct sun measured AOD at these same wavelengths were used to retrieve optical equivalent, column integrated aerosol size distributions and refractive indices. Using this microphysical information the spectral dependence of single scattering albedo is calculated. The algorithm of Dubovik and King (2000) with enhancements detailed in Dubovik et al. (2006) was utilized in these retrievals, known as Version 2 AERONET retrievals. Only Version 2 and Level 2 quality assured retrievals (Holben et al., 2006) are presented in this paper, unless otherwise noted. The Version 2 AERONET algorithm determines the percentage of spherical and spheroidal particles required to give the best fit to the measured spectral sky radiance angular distribution. Further details on the Version 2 algorithm and the improved specification of surface bidirectional reflectance can be found in Dubovik et al. (2006) and Eck et al. (2008). 
Almucantar sky radiance measurements were made at optical air masses of 4, 3, 2 and $1.7\left(75,70,60\right.$ and $54^{\circ}$ solar zenith angle, respectively) in the morning and afternoon, and once per hour in between. In order to ensure sky radiance data over a wide range of scattering angles, only almucantar scans at solar zenith angles greater than $\sim 50^{\circ}$ are analyzed and presented here. In order to eliminate cloud contamination from the almucantar directional sky radiance data, AERONET requires the radiances to be symmetrical on both sides of the sun at equal scattering angles, and symmetric radiances from both sides are subsequently averaged. Directional sky radiance measurements that are not symmetrical (due to cloud on one side or inhomogeneous aerosol distribution) are eliminated, and the minimum number of measurements required in given scattering angle ranges for a Level 2 retrieval are shown in Holben et al. (2006). The stable performance of the inversion algorithm was illustrated in sensitivity studies performed by Dubovik et al. (2000) where the perturbations of the inversion resulting from random errors, possible instrument offsets and known uncertainties in the atmospheric radiation model were analyzed. Their work employed retrieval tests using known size distributions to demonstrate successful retrievals of mode radii and the relative magnitude of modes for various types of bimodal size distributions such as those dominated by a sub-micron accumulation mode or distributions dominated by super-micron coarse mode aerosols. Although very few direct comparisons of size distribution between in situ and AERONET retrievals have yet been published, there are several aerosol types in specific regions that have been or can be compared. For example, Reid et al. (2005) presents a table were the volume median radius of smoke from various major biomass burning regions, South America, southern Africa, and North America (boreal, temperate), are compared. For all three of these regions, the volume median diameters of the in situ vs. the AERONET retrievals are often within $\sim 0.01 \mu \mathrm{m}$ of each other. Similarly, for fine mode pollution in the Arabian Sea during the Indian Ocean Experiment (INDOEX), Clarke et al. (2002) presented lognormal fits of volume size distributions from aircraft and ship in situ instrument measurements that showed average accumulation mode volume peak radius values of $0.17-0.18 \mu \mathrm{m}$ with geometric standard deviations of 1.43 (aircraft) and 1.51 (ship) for observations made under high aerosol scattering conditions. This compares well with retrievals made at Kaashidhoo Island, Maldives (in the same region), when $\operatorname{AOD}(440 \mathrm{~nm})>0.4$, of $0.18 \mu \mathrm{m}$ median radius and width of 1.49 (AERONET Version 2 averages from 1998-2000). For larger sub-micron sized aerosols, Eck et al. (2010) discussed the relatively close agreement for Pinatubo stratospheric aerosol observations of $\sim 0.56 \mu \mathrm{m}$ peak volume radius from AERONET retrievals to $0.53 \mu \mathrm{m}$ effective radius from in situ stratospheric aircraft measurements, as reported by Pueschel et al. (1994). In the coarse mode (super-micron radius), Reid et al. (2006, 2008) showed excellent agreement between in situ measured size and AERONET retrievals for sea salt and desert dust, respectively. Smirnov et al. (2003) showed reasonable agreement between AERONET retrievals of size distributions and in situ measurements for aerosols of marine origin. Similarly, Johnson and Osborne (2011) have shown good agreement between aircraft in situ measured size distributions and AERONET retrievals for coarse mode dust in the Sahel region of West Africa.

\subsection{Micro-pulse Lidar (MPL)}

Micro-pulse lidar (MPL) systems were used to obtain vertical profiles of aerosol and cloud backscatter at the GSFC and Edgewood sites. The baseline measurement obtained from an MPL (either at 527 or $532 \mathrm{~nm}$, depending on model) is an attenuated backscatter profile, the result from molecular and particle backscatter contributions that are attenuated due to the atmospheric transmission loss. These profiles can be extremely useful for the interpretation of vertically resolved atmospheric temporal dynamics for both clouds and aerosols. The system at GSFC is based on the standard MPL Type 4 model that is part of the NASA Micro Pulse Lidar Network (MPLNET) project (Welton et al., 2001) that routinely provides processed data available from the project's website (http://mplnet.gsfc.nasa.gov). During the DISCOVER AQ campaign, additional Sigma Space MPL systems were deployed by University of Maryland Baltimore County (UMBC) at multiple locations in the BaltimoreWashington region to provide supplemental profile coverage (Berkoff et al., 2012). These systems, including the one at Edgewood, utilized a version of the Sigma Space lidar referred to as mini-MPL. These systems are based on the MPL concept, but at a significant reduction in size and weight, making setup more practical for temporary field deployments. Data from these systems were processed by UMBC (along with quick-look images), and are available by groundsite name in the DISCOVER-AQ archive (http://www-air. larc.nasa.gov/missions/discover-aq/discover-aq.html).

The NASA MPLNET (Welton et al., 2001), is a federated network of ground-based MPL (532-527nm, Spinhirne et al., 1995) produced by Sigma Space and commercially available. The eye-safe lidar instruments, deployed worldwide, provide continuous information on the vertical structure of the atmosphere, collecting measurements autonomously in all meteorological conditions. Global measurements of aerosol and cloud microphysical and optical properties over a temporal period relevant to climate variations contribute to a better comprehension of their influence on radiative transfer and are therefore important in climate change studies. In addition, the network provides ground validation for models and satellite sensors in the frame of NASA Earth Observing System (EOS).

MPLNET is based on a federated approach, allowing independent research groups to join the network and set up their own site. Data processing and data storage is centralized at 
NASA GSFC, enabling a common set of algorithms to be applied to all sites, ensuring continuity in the data.

Single wavelength elastic backscattering lidars rely on critical assumptions to retrieve optical properties of aerosols (Fernald, 1984) that affect measurement accuracy. The inversion of the lidar equation is greatly improved and simplified by the presence of a sun photometer co-located with the lidar (Marenco et al., 1997). As a consequence, when possible, the MPLNET sites are co-located with AERONET sun-sky radiometers.

\subsection{High-spectral-resolution lidar (HSRL)}

The NASA Langley Research Center (LaRC) airborne HSRL-1 (Hair et al., 2008) measured profiles of aerosol extinction $(532 \mathrm{~nm})$, aerosol optical depth (AOD) $(532 \mathrm{~nm})$, backscatter (532 and $1064 \mathrm{~nm}$ ) and depolarization (532 and $1064 \mathrm{~nm}$ ) while deployed on the NASA Langley Research Center UC-12 King Air aircraft during the DISCOVER-AQ mission. The HSRL-1 measurements were acquired below this aircraft which flew at an altitude of about $9 \mathrm{~km}$ above sea level (a.s.1.). This airborne lidar uses the HSRL technique to independently retrieve aerosol (and tenuous cloud) extinction and backscatter (Grund and Eloranta, 1991; She et al., 1992; Shipley et al., 1983) without a priori assumptions on aerosol type or extinction-to-backscatter ratio. The LaRC HSRL-1 employs the HSRL technique at $532 \mathrm{~nm}$ and the standard backscatter technique at $1064 \mathrm{~nm}$. It also measures depolarization at both wavelengths. The instrument is selfcalibrating at $532 \mathrm{~nm}$ for measurements of cloud-aerosol backscatter and extinction, unlike standard backscatter lidars that are empirically calibrated by assuming that the aerosol contribution to backscatter is either negligible or known at some altitude. The HSRL-1 is also self-calibrating at both 532 and $1064 \mathrm{~nm}$ for measurements of depolarization. The overall systematic error associated with the backscatter calibration is estimated to be less than 2-3\%. Under typical conditions, the total systematic error for extinction is estimated to be less than $0.01 \mathrm{~km}^{-1}$ at $532 \mathrm{~nm}$. The random errors for all aerosol products are typically less than $10 \%$ for the backscatter and depolarization ratios for the nominal averages noted (Hair et al., 2008). Rogers et al. (2009) validated the HSRL extinction coefficient profiles and found that the HSRL extinction profiles are within the typical state-ofthe-art systematic error at visible wavelengths (Schmid et al., 2006). During the DISCOVER-AQ deployment, the HSRL acquired approximately $100 \mathrm{~h}$ of data over the BaltimoreWashington, D.C. area during 27 flights in July 2011.

\subsection{Airborne in situ aerosol instrumentation}

In addition to the UC-12, the NASA P-3B aircraft was involved during the DISCOVER-AQ and both were sampling in coordination with surface networks during field campaigns. The NASA P-3B aircraft performed 14 flights of nominal $8 \mathrm{~h}$ duration in the Washington, D.C.-Baltimore, MD, area in July 2011, with each flight normally involving two to four vertical profiles (spirals) per site, from 0.3 to $3.2 \mathrm{~km}$ (pressure altitude), over the Beltsville, Padonia, Fairhill, Aldino, Edgewood and Essex sites (see Crumeyrolle et al., 2014 for more details). The NASA P-3B was equipped with in situ aerosol instruments to measure microphysical, optical and chemical properties of aerosols. Aerosols were sampled through an isokinetically controlled inlet designed for clear sky sampling only. Data contaminated by cloud penetrations (droplet shattering on the inlet tip) were identified visually via high particle number concentration and thus removed. During nominal conditions, particles smaller than $4 \mu \mathrm{m}$ diameter are efficiently transmitted (McNaughton et al., 2007) and delivered to a comprehensive suite of aerosol instruments.

Simultaneous measurements of aerosol size distribution, scattering $\left(\sigma_{\text {scat }}\right)$ and absorption $\left(\sigma_{\text {abs }}\right)$ coefficients and aerosol chemical composition were made during DISCOVER-AQ. An ultra-high sensitivity aerosol spectrometer (UHSAS, Droplet Measurement Technologies) performed size distribution measurements $(1 \mathrm{~Hz}$ frequency) of dry aerosol with diameters from 0.06 to $1.0 \mu \mathrm{m}$. The UHSAS was calibrated with polystyrene latex spheres (PSL) and post-corrected with ammonium sulfate in order to provide optical particle sizing most representative of ambient aerosol.

Along with the size distribution measurements, dry scattering coefficient $\left(\sigma_{\text {scat }}\right)$ measurements were made at $1 \mathrm{~Hz}$ using a three-wavelength nephelometer (TSI 3563) operating at 450,550 and $700 \mathrm{~nm}$ at RH less than $40 \%$. The nephelometer was calibrated using filtered air and $\mathrm{CO}_{2}$ (Anderson and Ogren, 1998) prior to, during, and after the mission. The scattering coefficient has been corrected from angular truncation errors and illumination intensity issues based on Anderson and Ogren (1998). The comparison of the $\sigma_{\text {scat,dry }}$ measurements to the modeled $\sigma_{\text {scat,dry }}$ calculated using Mie theory reveals good agreement (slope of $0.991 \pm 0.004$ and $r^{2}$ of 0.98 ) and gives confidence in both the $\sigma_{\text {scat,dry }}$ and dry size distribution measurements (Ziemba et al., 2013). An additional and parallel three-wavelength integrating nephelometer operating at a RH controlled at $80 \pm 4 \%$ (Ziemba et al., 2013) was used to measure the wet scattering coefficient. The sample flow routed to both nephelometers was actively dried using a Nafion dryer (Perma-Pure FC-125-240-10PP) which efficiently passed accumulation mode aerosol (> $90 \%$ transmission).

An empirical dependence of the scattering coefficient on relative humidity (Kasten, 1969; Carrico et al., 1998) is used to estimate the particle hygroscopicity and to convert the measured extinction coefficient from dry $\left(\sigma_{\text {ext,dry }}\right)$ to the ambient humidity conditions $\left(\sigma_{\text {ext,amb }}\right)$. Ziemba et al. (2013) compared in situ extinction coefficient measurements (adjusted to $532 \mathrm{~nm}$ ) coincident with remote-sensing observations performed by the HSRL (measured at $532 \mathrm{~nm}$ ). This comparison revealed good agreement (slope 1.11 and 
$\left.R^{2}=0.88\right)$ consistently over the entire ambient RH range within instrumental uncertainty. The good agreement demonstrated that (1) all the particles observed by the HSRL are within the sampling size range of the in situ measurements (i.e., particles observed in this region are smaller than the inlet cutoff diameter of $4 \mu \mathrm{m}$ ) and (2) the empirical parameterization is valid to correct observations performed at dry $\mathrm{RH}$ to ambient conditions.

Aerosol chemical composition measurements were made with a pair of particle-into-liquid samplers (PILSs). The first PILS was coupled to a total organic carbon (TOC) analyzer (Sievers Model 800) to give the mass of the watersoluble organic carbon at a $10 \mathrm{~s}$ time resolution. The output of the second PILS were collected in $0.8 \mathrm{~mL}$ vials for later ion chromatographic measurement of sodium, ammonium, potassium, calcium, magnesium, chloride, nitrite, nitrate and sulfate. Sampling intervals for the inorganic analysis varied between three to five minutes.

\section{Results}

\subsection{AERONET surface measured AOD before and after cumulus cloud development}

In this section we focus on two days during the month of July 2011 where large diurnal dynamics in measured AOD were noted at some AERONET sites within the DRAGON network. On 5 July 2011, the DRAGON_Essex site ( 12 km east-northeast of downtown Baltimore) showed a particularly large increase in AOD near solar noon $(\sim 17: 00$ UTC $)$ as shown in Fig. 3a. In fact the AOD at $500 \mathrm{~nm}$ jumped from $\sim 0.33$ to $\sim 0.58$ in only 13 min and remained similarly high for the remainder of the day. This is the Level 1.0 AERONET data with no cloud screening applied, in order to include data that has high temporal variance, particularly high triplet variance. During this time period when AOD increased by approximately $75 \%$ in only minutes, the Ångström exponent remained relatively constant with no significant temporal trend throughout the day. The temporal regression fit to the $440-870 \mathrm{~nm}$ Angström exponent (Fig. 3b; computed by linear regression of the 440,500, 675 and $870 \mathrm{~nm}$ AOD) showed nearly zero slope and an average value of 1.97 , indicating the dominance of very small fine mode particles and no significant cloud contamination (Eck et al., 1999; Holben et al., 2001). The short wavelength Ångström exponent from 380 to $500 \mathrm{~nm}$ (computed by linear regression of 380,440 and $500 \mathrm{~nm}$ AOD) is more sensitive to small variations in submicron particle radius (Reid et al., 1999; Eck et al., 2001). This, however, also remained relatively stable with the regression only accounting for $\sim 4 \%$ of the variance, thereby suggesting no significant change in fine mode particle radius. In Fig. 4 we show the relationships between these Ångström exponents and volume median radius of the fine mode from AERONET almucantar retrievals using the
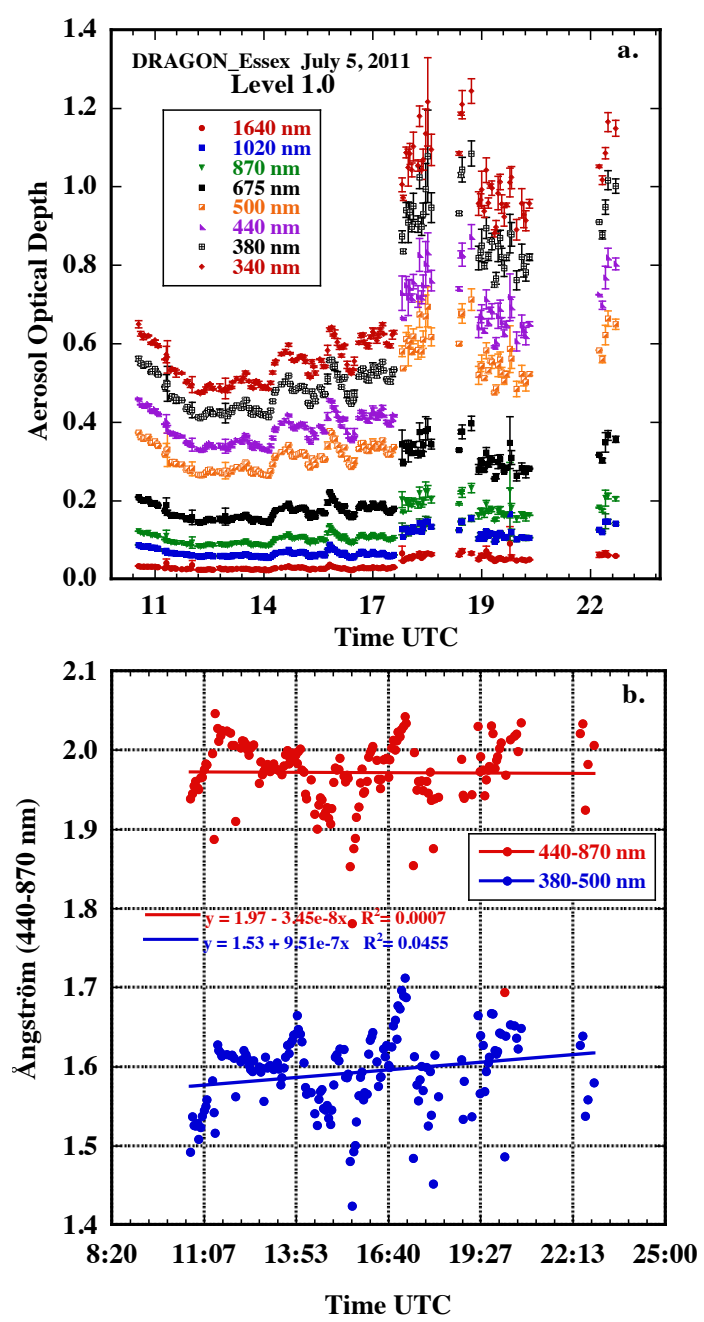

Figure 3. (a) The time series of spectral AOD measured at the DRAGON_Essex AERONET site on 5 July 2011, for data with no cloud screening (Level 1.0). The bars shown are \pm half of the AOD triplet range (maximum-minimum AOD). (b) The time series of the Angström exponent computed for two wavelength intervals from the same data as in (a), including the linear fit to both.

climatological data at the GSFC, Maryland site (> 1600 retrievals). Only data where the AOD at $440 \mathrm{~nm}$ is greater than 0.2 and fine mode fraction $>90 \%$ are shown, in order to insure high accuracy in both the computations of Ångström exponent and in retrievals of the fine mode radius for accumulation mode dominated cases. The second order polynomial fit of fine mode radius vs. 440-870 nm Ångström exponent only explained $\sim 43 \%$ of the variance, while the 380 $500 \mathrm{~nm}$ Angström exponent explained $\sim 76 \%$ of the variance thereby quantifying the greater sensitivity of the shorter wavelength Angström exponent to fine mode particle size.

It is noted that the AOD measurement frequency made at the DRAGON_Essex site (Fig. 3a) is much greater than the standard $15 \mathrm{~min}$ interval of AERONET. For this campaign several Cimels were operated with a 3 min sampling 

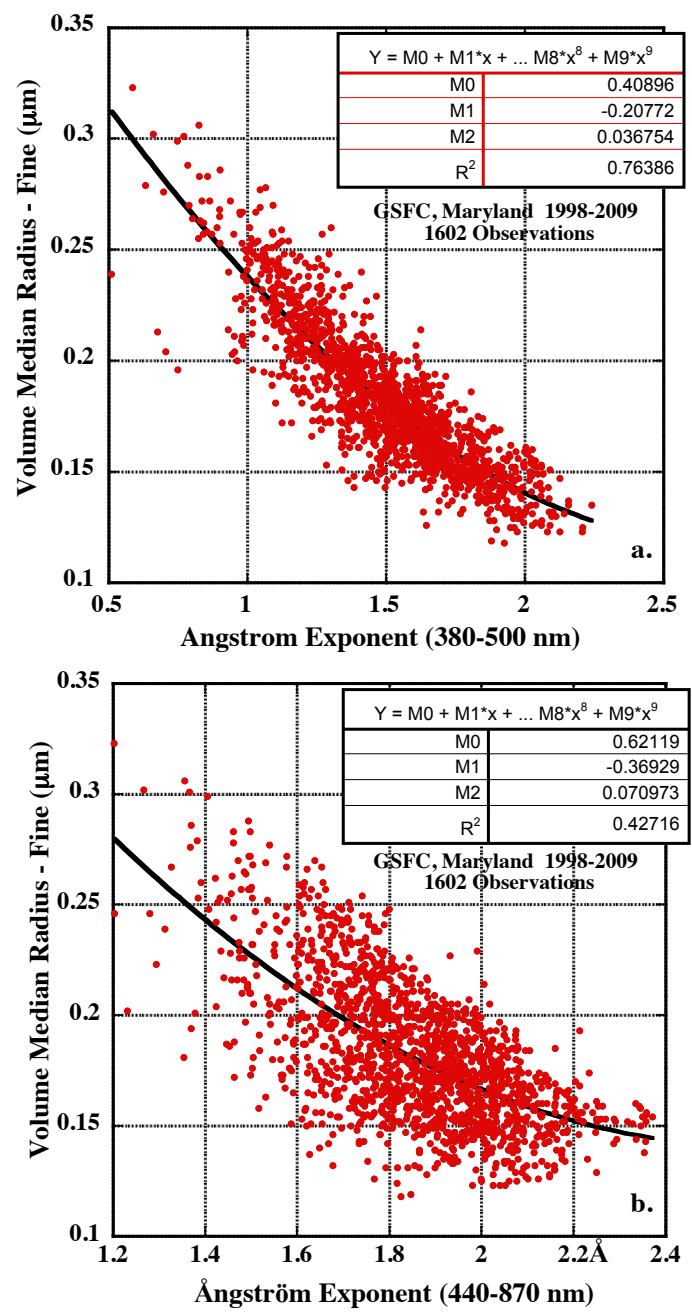

Figure 4. Relationship between the fine mode radius retrieved from the Dubovik and King (2000) algorithm and the Ångström exponent (for two different wavelength intervals) for the GSFC site. The Level 2.0 (cloud screened and quality assured) climatological data from 1998 to 2009 are shown for AOD $(440 \mathrm{~nm})>0.2$ and fine mode fraction $>0.90$.

interval to obtain higher temporal resolution data. For the entire morning interval of measurements $(\sim 10: 30-17$ :00 UTC) there were no gaps in the measured AOD except for sky radiance scans made at optical air masses of $\sim 4,3,2$ and 1.7 (corresponding to solar zenith angles of $\sim 75,70,60$ and $54^{\circ}$, respectively) and hourly afterwards. This implies very low cloud cover fraction, and in fact hourly geostationary operational environmental satellite (GOES) East visible images show relatively cloudless skies over the site through the morning hours. However, the afternoon AOD data at the site show large gaps, for example most of hour 18:00 and also from $\sim 20: 40$ to 22:20 UTC, and satellite data (both GOES and moderate resolution imaging spectroradiometer (MODIS) Aqua; see below), indicate significant cumulus cloud cover. In addition to the average AOD in a one-minute interval, the range of AOD from the three measurements made $30 \mathrm{~s}$ apart are also plotted in Fig. 3a depicting the full measured AOD range (maximum-minimum) as equal-length bars. This AOD range or triplet variability is notably larger in the afternoon hours vs. the morning, indicating much greater high frequency variation in AOD in the afternoon during the time of cumulus cloud development. In fact, the triplet range was high enough to exceed the cloud-screening triplet range threshold (0.02; Smirnov et al., 2000) for most afternoon observations (see Sect. 4) for the AERONET Version 2 Level 1.5 and 2 databases (both having automated cloud screening).

Figure 5 shows the time series of total, fine and coarse mode daily average AOD at $500 \mathrm{~nm}$ from the SDA algorithm for several AERONET sites on 5 July 2011. These are Level 1 data (non-cloud-screened), but with full calibrations applied, which have had the SDA algorithm applied to the AOD spectra. The coarse mode AOD at the most of these sites are $\sim 0.01-0.025$ nearly all day suggesting that almost all of the variability in total AOD is due to fine mode pollution aerosol. The locations of these sites are shown on the MODIS Aqua image from 18:30 UTC (early afternoon) on this date. From Fig. 5 it is noted that sites in near proximity to the larger cumulus clouds showed significant afternoon increases in fine mode AOD (see BLDND and MNKTN sites for examples), while sites that were in relatively cloudless regions or had mostly small cumulus cloud cells showed relatively stable AOD from morning through afternoon (see GSFC and CLRST sites for examples).

It is noted that there is substantially less cloud contamination from cumulus clouds vs. cirrus clouds in the AERONET Version 2 Level 1.0 AOD data. This is due to the significantly larger temporal variance of cloud optical depth (COD) in cumulus and higher optical depths of most cumulus clouds compared to most cirrus clouds. Thus the AOD triplet variability (the principal cloud-screening check) typically shows significantly more temporal variance due to cumulus cloud presence than for cirrus clouds. Of course for all clouds the COD is underestimated relative to true cloud optical depth due to strong forward scattering by large (relative to aerosol size) cloud droplets or ice crystals into the Cimel instrument field of view. However, this effect is less for typical water droplets in cumulus clouds $(\sim 20-40 \%$ underestimate) than for larger ice crystals in cirrus ( $\sim$ up to $100 \%$ underestimate) as shown by Kinne et al. (1997) for simulation of the effects of cloud on sun photometer measurements. Additionally, although the Level 1.0 AOD data do not have the AERONET cloud-screening algorithm of Smirnov et al. (2000) applied, there is still a basic filter of large temporal variance of the signal applied to all Level 1.0 data. The direct sun measurement data are not included in the AERONET Level 1.0 data set if the variance of the raw signal is very high within the triplet sequence. The variance threshold applied is based on the root mean square (RMS) differences of the three direct sun triplet measurements relative to the mean of these 

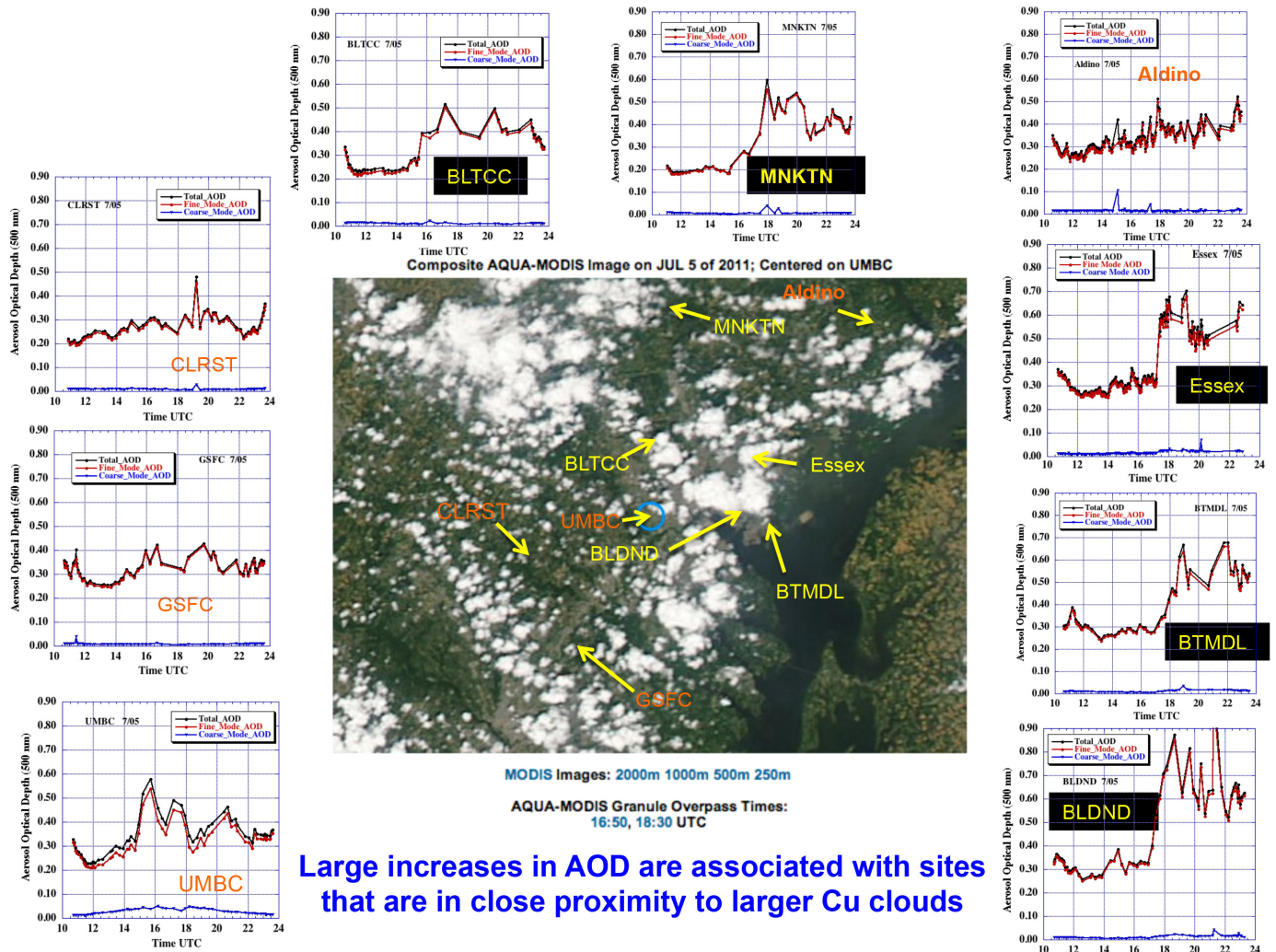

Large increases in AOD are associated with sites that are in close proximity to larger Cu clouds

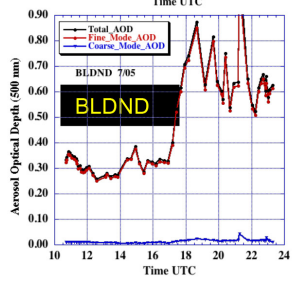

Figure 5. The Aqua MODIS satellite image centered on the UMBC site for 5 July 2011, showing the locations of selected AERONET sites. The time series of the fine and coarse mode AOD for each of these AERONET sites as determined by the spectral deconvolution algorithm (SDA) are also shown.

three values. If the (RMS/mean) $100 \%$ of the triplet values is greater than $16 \%$ then the data will not be used for computation of AOD and the data will not appear in the Level 1.0 data set. This temporal variance threshold primarily removes data that are affected by clouds with large spatial-temporal variance in COD. This effectively removes much of the cumulus cloud contaminated data, although some of the thinner edges with lower COD do remain in the data; see the decreases in Angström exponent in Fig. $6 \mathrm{~b}$ and the increases in coarse mode AOD in Fig. $8 \mathrm{~b}$ for examples.

\subsection{AERONET retrievals of aerosol size distributions before and after cumulus development}

High quality retrievals of aerosol optical properties from almucantar sky scan retrievals are very difficult to achieve in situations where there is a significant cloud fraction present. The presence of clouds typically precludes enough measurements of cloud free sky radiance to be able to meet retrieval thresholds (Holben et al., 2006) that were determined necessary in order to have a sufficient aerosol signal for a robust retrieval. Additionally, the spatial variance of AOD associated with cumulus interactions may also result in large retrieval errors due to irregular angular variance of sky radiances associated with variable aerosol loadings. Even during the DISCOVER-AQ campaign when there were 40 Cimels distributed in central Maryland, there were very few sites/dates when almucantar retrievals were made before and after cumulus cloud development at sites that exhibited large increases in AOD associated with cloud presence. One of these rare cases occurred on 5 July 2011 at the DRAGON_MNKTN site (located in Monkton, Maryland). The spectral AOD and related Ångström exponents for this case are shown in Fig. 6a and b, respectively. Large gaps in direct sun measured AOD occurred after 15:20 UTC associated with the cumulus clouds, and the AOD increased significantly, except for some cloud contamination in two observation points between 17:00 and 19:00 UTC when AOD and its triplet variability increased significantly and Ångström exponents decreased sharply. Except for the two partially cloud contaminated points there was no trend observed in the 440-870 nm Ångström exponent from before, during and after cumulus development, with values very high, mostly $>2.1$; thereby indicating that the increase in AOD was dominated by fine mode particles with minimal coarse mode contribution. The shorter wavelength Ångström exponent (380$500 \mathrm{~nm}$ ), however, exhibited a slight decrease in time starting at $\sim 1.74$ in the morning and ending at $\sim 1.64$ in the 

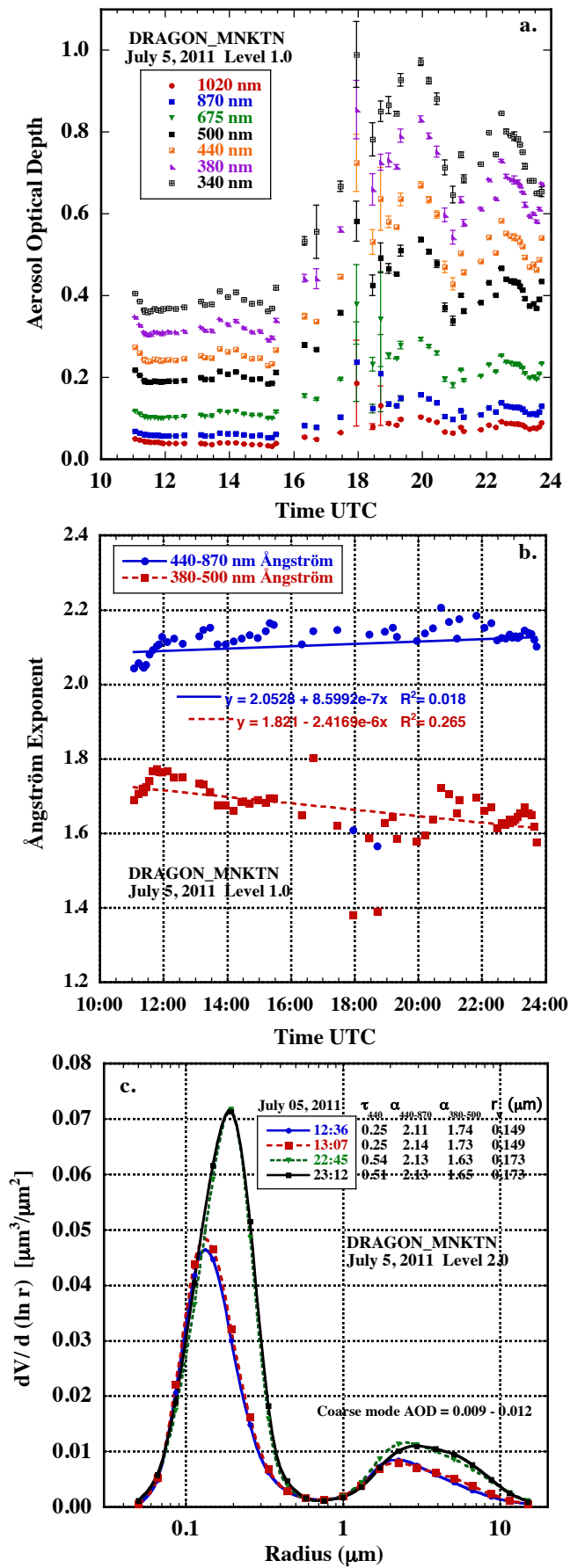

Figure 6. (a) Time series of the spectral AOD (with triplets shown) at the DRAGON_MNKTN site on 5 July 2011 (see Fig. 5 for the fine and coarse mode time series). (b) Time series of the Ångström exponent for two wavelength intervals for the same data set. (c) Volume size distribution retrievals made in early morning and late afternoon, both before and after cumulus cloud formation and then dissipation. late afternoon, suggesting a slight increase in fine mode particle size (Reid et al., 1999; Eck et al., 1999, 2001). The Level 2 retrievals of volume aerosol size distributions on this date/site are shown in Fig. 6c, with two retrievals made in the morning before cloud formation and two after most clouds had dissipated in the late afternoon. These retrievals also show the dominance of fine mode to the total AOD with very low coarse mode AOD (coarse particles have radius $>0.76 \mu \mathrm{m}$; inflection point between modes), computed as ranging from 0.009 to 0.012 for the four almucantars shown. The retrieved fine mode size distributions show a distinct increase in the particle radius for the larger size radius values of the mode, while the minimum radius envelope of the fine mode remains constant. Computations of the median radius of the fine mode show an increase from $0.15 \mu \mathrm{m}$ for the two morning retrievals vs. $0.17 \mu \mathrm{m}$ for the two afternoon retrievals. These size distribution retrievals and $380-500 \mathrm{~nm}$ Ångström exponent both suggest that at least some of the increased AOD ( 0.54 at $440 \mathrm{~nm}$ in afternoon vs. 0.25 in morning) was associated with particle growth, likely from humidification (Twohy et al., 2009; Ziemba et al., 2013) and/or cloud processing.

Another case where retrievals of aerosol size distributions were made before, during and after the cumulus cloud convection cycle occurred at the GSFC site, not during the DISCOVER-AQ campaign but on 15 July 2013. The Aqua and Terra MODIS images (Fig. 7a and b) show very few cumulus clouds at $\sim$ 15:30 UTC vs. significant cumulus development at 18:45 UTC. Both the spectral AOD (Fig. 7c) and fine mode AOD from SDA suggest very large relative increases in the time interval when fair weather cumulus were present relative to the morning, a threefold increase of AOD at $440 \mathrm{~nm}$. Retrievals of aerosol size distribution were made before significant cloud formation (11:20 to 14:15 UTC; four retrievals), during a break within the cumulus convective cycle (20:15 UTC) and late in the day (23:09 UTC) likely after cumulus clouds had largely dissipated (Fig. 7c). While the coarse mode remained relatively constant (coarse AOD varied from $\sim 0.02$ to 0.04 as computed from the retrievals) the amplitude of the fine mode size distribution increased dramatically. The fine mode volume median radius computed from the two afternoon retrievals was quite small at $\sim 0.137 \mu \mathrm{m}$, significantly smaller than the morning values which ranged from $\sim 0.16$ to $0.175 \mu \mathrm{m}$. These smaller radius fine mode particles during and after $\mathrm{Cu}$ cloud development suggest possible new particle formation from $\mathrm{Cu}$ cloud interaction or humidification of Aitken mode particles, rather than humidification of existing accumulation mode particles or cloud processing of existing accumulation mode particles on this day. 

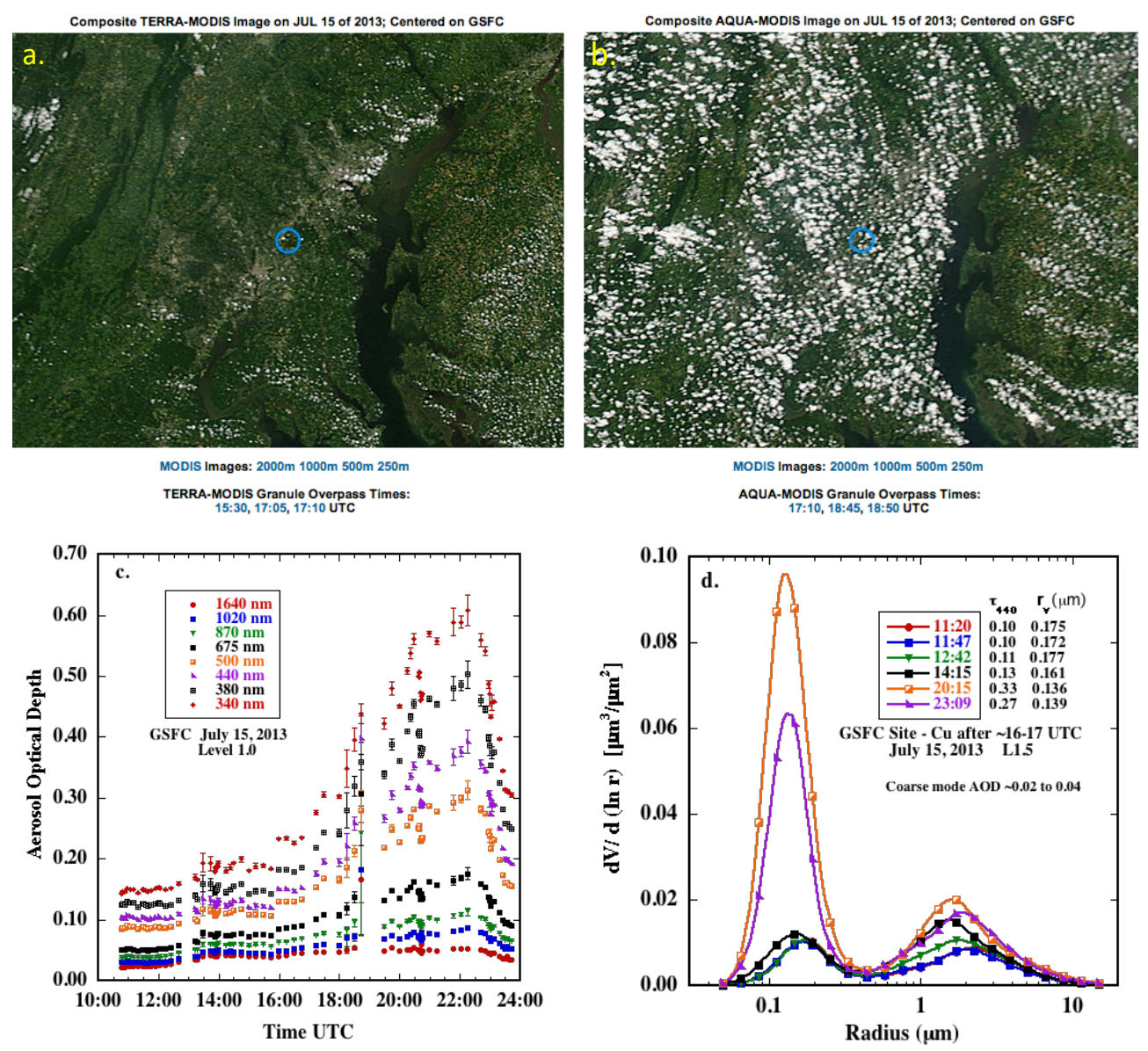

Figure 7. Both Terra and Aqua MODIS images (a) and (b) centered on the GSFC site (blue circle) on 15 July 2013. The spectral AOD time series from this day (c) and the volume size distribution retrievals (d) from before, during and after cumulus cloud formation are shown.

\subsection{Ground-based MPL LIDAR observations of aerosol enhancement near cumulus clouds}

Perhaps the most complete description of localized and rapid AOD enhancement occurred on 10 July 2011. The morning air over the greater Washington, D.C.-Baltimore area was nearly cloudless on this date. Examination of the 12:00 UTC Dulles airport radiosonde showed light winds on the order of $2-4 \mathrm{~km} \mathrm{~h}^{-1}$ and $\sim 50 \% \mathrm{RH}$ to $1.5 \mathrm{~km}$ altitude. No Terra MODIS retrieval (late morning) of AOD at $550 \mathrm{~nm}$ was above 0.3 within hundreds of kilometers of the study region. Figure 8 a shows a time series of GOES 13 visible images. At 14:15 UTC the very first signs any cloud activity was observable, only in the southern part of the image. Within an hour, cumulus humilis covered the entire region, and by 16:00 UTC, many cells had grown significantly to congestus size. At 18:00 UTC, congestus cells were fully developed, with clear areas around these cells likely due to downdrafts between the large clouds. Importantly, one can observe a near lack of movement in these cells. Noted with arrows are three example cells in the research domain that we followed in imagery nearly every $15 \mathrm{~min}$; they are moving at less than
$2 \mathrm{~km}$ per hour. Higher spatial resolution can be gained by examining MODIS on Terra and Aqua at $\sim 250 \mathrm{~m}$ resolution between 15:30 and 18:45 UTC (Fig. 8a, bottom row), when significant non-precipitating convection developed throughout the region.

The fine and coarse mode AOD retrieved from AERONET measurements (Fig. 8b) at the GSFC site indicate significant increases in fine mode AOD during the period of cumulus cloud development described above. Additionally, the GSFC site has a continuously operating ground-based MPL instrument that is part of the MPLNET global network of groundbased lidars (Welton et al., 2001). Figure 8c shows the MPL measured vertical profiles of the total attenuated backscattering, in blue, and the molecular attenuated backscattering, in red, at two different times (21:43 UTC upper; 12:29 UTC lower). This analysis methodology for lidar data verifies that the normalization in the aerosol-free region is correct. As can be seen, the blue and red curves are coincident above $3.7 \mathrm{~km}$ (where the aerosol signal is minimal and the molecular signal dominates). In this figure the area between the red curve and the blue curve is proportional to the AOD, therefore the 

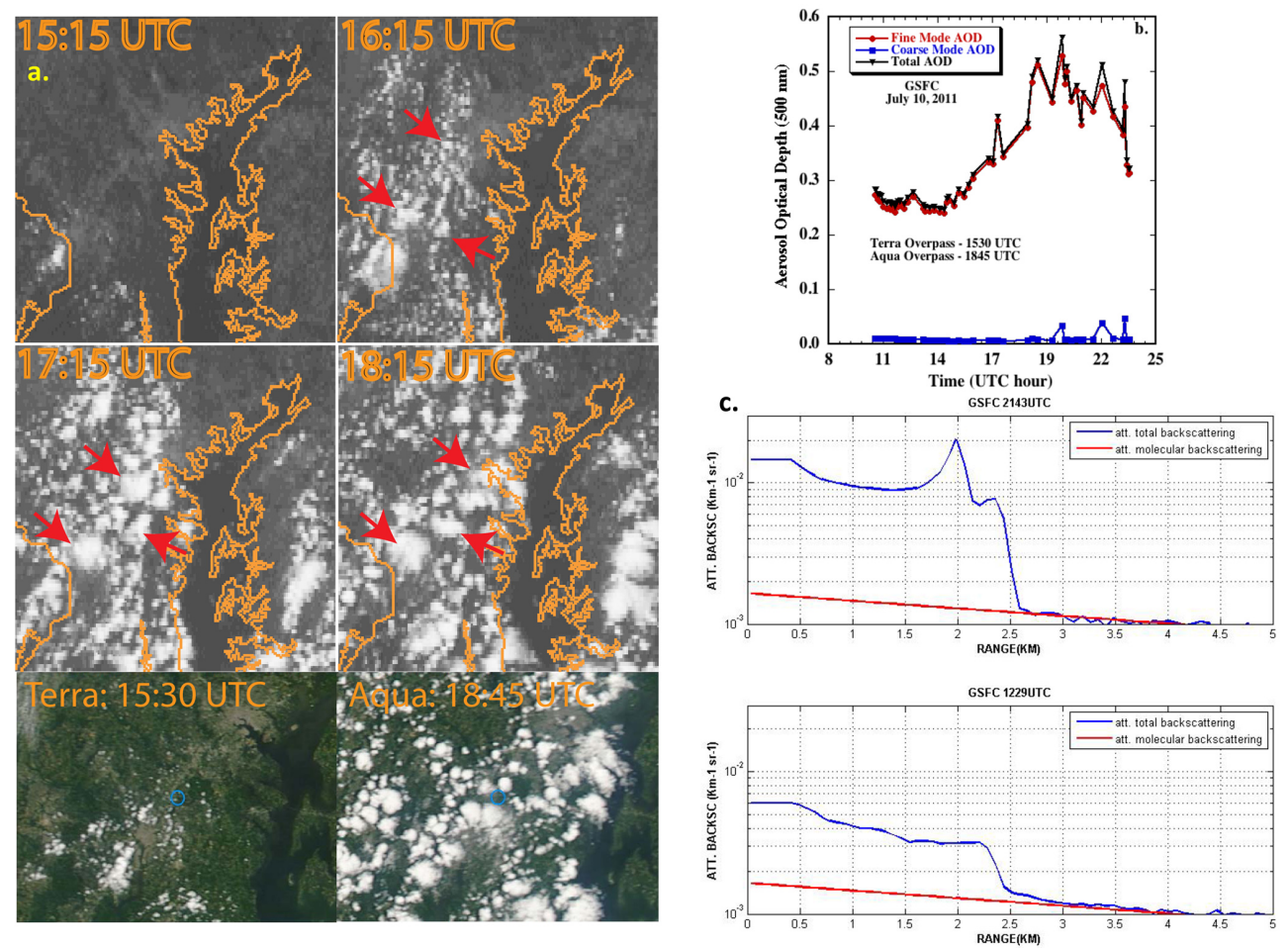

Figure 8. (a) GOES 13 images from 10 July 2011 at four observation times over a $3 \mathrm{~h}$ interval, with fixed location red arrows to show relative movement and growth of cumulus cells. Bottom row shows Terra and Aqua MODIS images acquired on 10 July 2011, centered on the GSFC site (blue circle). (b) The time series of fine and coarse mode AOD at the GSFC site for this same date. (c) Attenuated backscatter vertical profiles measured from micro-pulse lidar network (MPLNET) at the GSFC site on this same date from before and after cumulus formation, depicting both total and molecular backscattering.

larger the area, the higher the AOD. It can be seen in Fig. 8c that there is a difference of an order of magnitude between the two blue curves at around $2 \mathrm{~km}$, while at lower and higher altitudes, the difference is about a factor of 4 or 5 . Therefore at $\sim 2 \mathrm{~km}$ between 12:29 and 21:43 UTC there was a large increase in aerosol signal coincident with the increase in cumulus cloud fraction (Cu height base height determined from MPL data varied from $1.4 \mathrm{~km}$ at $16: 10$ UTC to $1.7 \mathrm{~km}$ from 17:35 to $23: 15$ UTC).

Several surface-based MPL instruments were co-located at selected AERONET sites during the Maryland DRAGON campaign in July 2011 (Berkoff et al., 2012). In Fig. 9a we show the AERONET measured time series of spectral AOD on 10 July 2011 at the Edgewood site, which also had a MPL instrument. The SDA retrieval of fine and coarse mode AOD (Fig. 9b) shows that fine mode dominates the temporal variance except for the first observation point that is cloud contaminated. For this first point, the cloud is cirrus (altitude $>8 \mathrm{~km}$; Fig. 9c) and therefore at a much higher altitude than the principal aerosol layer. Note that the fine mode AOD for this one mixed aerosol-cloud observation is consistent with the subsequent non-cloud contaminated observations. The late afternoon AOD from 19:00 to 21:00 UTC shows many data gaps due to cumulus clouds obscuring the sun.
During this period of time the fine mode AOD increased significantly, by a factor of 2-3 from the time before cumulus development. The co-located MPL lidar attenuated backscatter signal composite (Fig. 9c) confirms a sharp increase in the aerosol backscatter signal at around $\sim 1.7 \mathrm{~km}$ from 19:00 to 23:00 UTC, showing a complex situation with simultaneous presence of aerosols and clouds. The latter can be easily detected on the composite plot, as due to the high optical depth the signal is completely attenuated after few hundred meters from cloud base shown in black in the plot. Cloud bases determined from lidar at the Edgewood site on this day were primarily distributed at $\sim 1.8 \mathrm{~km}$ above ground level (a.g.l.).

\subsection{Airborne HSRL observations of aerosol enhancement near cumulus clouds}

The NASA Langley HSRL (Hair et al., 2008; Rogers et al., 2009; Burton et al., 2010, 2013) was flown on the NASA UC-12 King Air aircraft on 14 days during the DISCOVERAQ Maryland field campaign in July 2011. Here we focus on the HSRL measurements made in the afternoon of 10 July 2011 to investigate the aerosol signal as measured by HSRL in the vicinity of cumulus clouds. HSRL lidar pulses were made at $2 \mathrm{~s}$ time intervals during the campaign, and analysis 

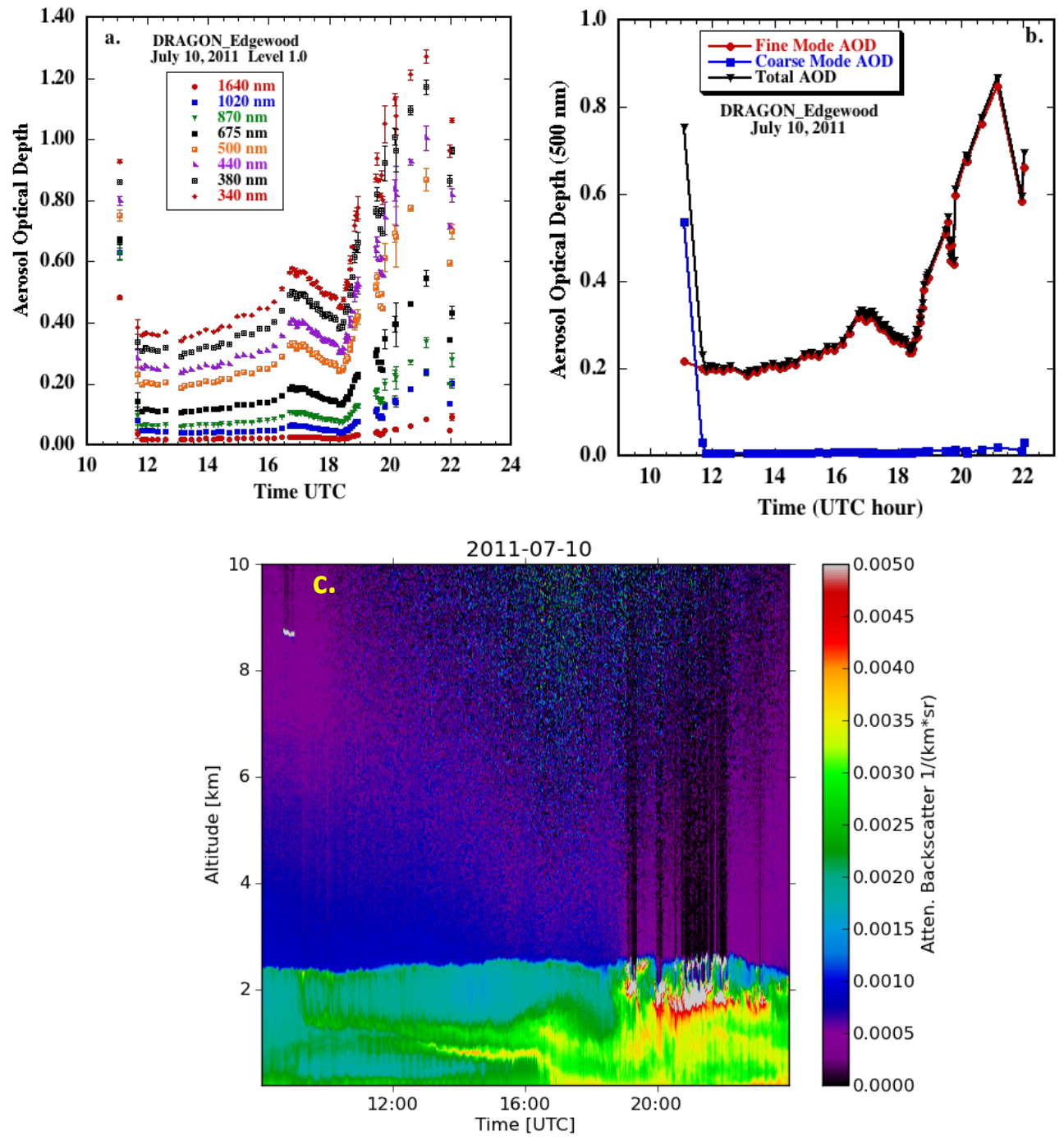

Figure 9. Time series of spectral AOD (a) and fine and coarse mode AOD (b) for the DRAGON_Edgewood site on 10 July 2011. MPL lidar measured time series of attenuated backscatter coefficient (c) at this same site and date. Note that cumulus cells first appearing at $\sim$ 19:00 UTC resulted in complete attenuation of the laser signal, showing as black above the cloud level.

of the data provided $30 \mathrm{~m}$ vertical resolution for the aerosol backscatter signal and $300 \mathrm{~m}$ vertical resolution for aerosol extinction. Figure 10a shows an example lidar curtain of aerosol backscatter from $15 \mathrm{~min}$ of HSRL profiles taken on 10 July 2011, with the resulting data extending for $\sim 90 \mathrm{~km}$ linear distance. Collocated digital images (Fig. 10b shows an example) coupled with the lidar profiles allowed for determination of the distance from clouds in all directions of the individual lidar profiles. These data were utilized to investigate aerosol properties adjacent to clouds compared to those some variable distance away from clouds. The HSRL data provides the unique perspective of being able to investigate the spatial extent of the influence of cumulus clouds on aerosol properties. For most parameters (except total column AOD), the lidar profile data were averaged from $50 \mathrm{~m}$ below to $200 \mathrm{~m}$ above cloud top to help isolate cloud influences on aerosol parameters.

Figure 10c shows the inferred aerosol extensive parameters retrieved from HSRL data as a function of distance from clouds. The total vertically integrated AOD from ground surface level to $7 \mathrm{~km}$ (aircraft altitude) decreased by an average of $\sim 20-25 \%$ from near the cloud to $4.5 \mathrm{~km}$ distance from cloud, with most of this decrease occurring in the closest $2.5 \mathrm{~km}$ to cloud edge. Therefore, the HSRL data show AOD enhancement in the near-cloud vicinity, consistent with that suggested by the AERONET data in Sect. 3.1 for selected sites on the same date 10 July 2011. The magnitude of the change in AOD associated with clouds was greater than $25 \%$ at the Edgewood and GSFC AERONET sites than that observed by HSRL for all clouds averaged on the same date. This may be due in part to possible 

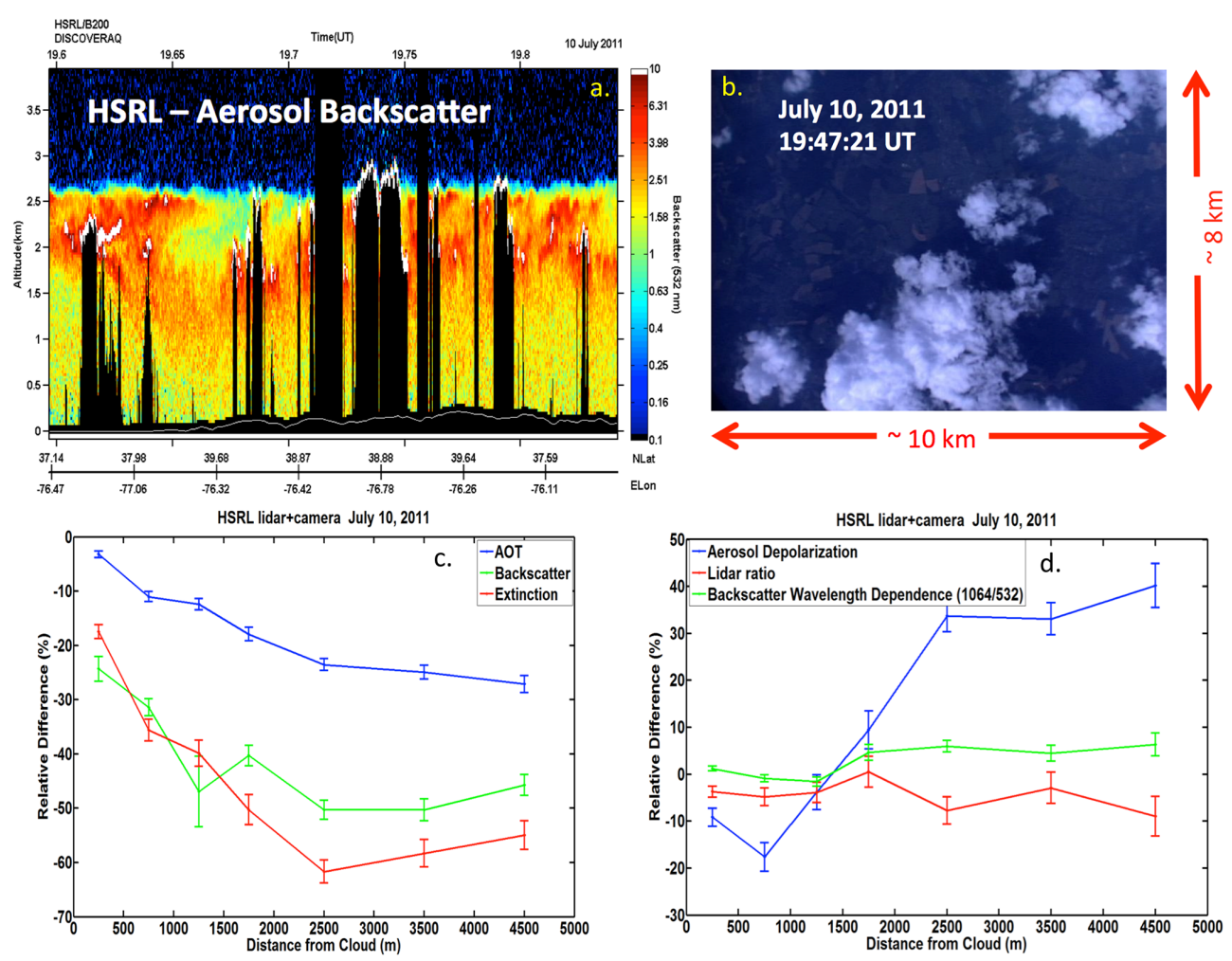

Figure 10. (a) Downward viewing HSRL measured backscattering coefficient $(532 \mathrm{~nm})$ from a 15 min flight segment corresponding to a $\sim 90 \mathrm{~km}$ transect on 10 July 2011 in the Maryland study region. (b) An example digital camera image taken coincident with the HSRL data in order to determine the distance from cloud of each lidar scan pulse. (c) Aerosol extensive parameters (backscatter, extinction, and AOD) inferred from HSRL data as a function of distance from the cloud edge. (d) Aerosol intensive parameters (depolarization, lidar ratio, and backscatter wavelength dependence) inferred from the HSRL data as a function of distance from the cloud edge.

smaller effects (magnitude and spatial extent) for smaller cumulus cloud cells, as the HSRL is averaged regardless of cloud size, while the cumulus cells near to these two AERONET sites shown had larger size cumulus cells. Yang et al. (2012) found relatively larger increases in CALIPSO measured aerosol backscatter associated with larger horizontal dimension clouds. For cumulus clouds in the intertropical convergence zone over the eastern Pacific near Mexico, Jiménez-Escalona and Peralta (2010) analyzed in situ aircraft observations showing large increases in AOD from near to clouds (within $500 \mathrm{~m}$ ) to $1500 \mathrm{~m}$ away from clouds (an average of a factor of 10 increase), for deep convective clouds with bases $\sim 300 \mathrm{~m}$ a.s.l. and tops exceeding $6 \mathrm{~km}$.

HSRL measured aerosol backscatter and extinction near the cloud altitude of $\sim 2-2.5 \mathrm{~km}$ a.g.l. both decreased by $\sim 50-60 \%$ from near clouds to $\sim 2.5 \mathrm{~km}$ from cloud edges. These aerosol enhancements at cloud altitude are quite large and the result is a significant restructuring of the aerosol vertical profile, as can be seen in Fig. 10a, with the creation of an enhanced layer aloft. Studies by Ford and Heald (2013) and Wonaschuetz et al. (2012) both found significant modification of aerosol vertical profiles as a result of cumulus cloud influences on aerosol production/modification. HSRL data were also utilized to investigate selected intensive aerosol optical properties as a function of distance from cumulus cloud cell edges. In Fig. 10d the lidar ratio and backscatter wavelength dependence $(1064 / 532 \mathrm{~nm})$ show no significant trend as a function of distance from cloud edge. Both of these parameters are largely dependent on aerosol size and secondarily absorption properties (Ackermann, 1998; Müller et al., 2007; Sasano and Browell, 1989); therefore, the HSRL data suggest that there is little change in aerosol size associated with the cloud enhanced aerosol signal, which is consistent with AERONET measured Ångström exponent (Fig. 3b). However, aerosol depolarization increases by $\sim 30-40 \%$ as distance from the cloud edges increases from near cloud to $2.5 \mathrm{~km}$ from the cloud. This is consistent with the possibility of the aerosol being more spherical in shape near the clouds (Murayama et al., 1996; Sassen, 2000), which may occur as a result of humidification, cloud processing, and new particle formation in the clouds. This behavior of aerosol extensive (backscatter, extinction, AOD) and intensive (lidar ratio) parameters is similar to that measured by the HSRL-1 and the ground-based Raman lidar above the Department of Energy Southern Great Plains Climate Research Facility during the Cumulus Humilis Aerosol Processing 
Study (CHAPS-June 2007) and Routine ARM Aerial Facility (AAF) Clouds with Low Liquid Water Depths (CLOWD) Optical Radiative Observations (RACORO-June 2009) campaigns (Ferrare et al., 2011).

\subsection{Airborne in situ observations of aerosol enhancement near cumulus clouds}

In situ measurements were made within the aerosol layer from aircraft during the DISCOVER-AQ Maryland campaign during July 2011 . These data were taken at altitudes a.g.l. ranging from $\sim 0.3 \mathrm{~m}$ to $3.2 \mathrm{~km}$ in spiral flight patterns lasting $\sim 15 \mathrm{~min}$ over selected sites. These in situ aerosol measurements were acquired from the NASA P-3B aircraft by the NASA Langley Aerosol Group Experiment (LARGE; Ziemba et al., 2013; Crumeyrolle et al., 2014) utilizing their instrument package to characterize aerosol chemical, optical and microphysical properties. Here we consider the in situ measurements made on 10 July 2011 from spiral flights made over the Edgewood site. This is the same case (site and date) as the AERONET AOD and MPL lidar data shown in Fig. 9a and c, respectively. In Fig. 11a the vertical profiles of dry scattering coefficient at $550 \mathrm{~nm}$ measured from four spiral flights at the Edgewood site are shown. Two of these profile flights occurred before cumulus cloud formation and two profiles after cloud formation (see the time series of AOD and lidar backscatter in Fig. 9). As seen in the figure, the scattering coefficients are significantly higher after cloud formation, especially for altitudes ranging from $\sim 1$ to $\sim 2.5 \mathrm{~km}$, by a factor up to $\sim 1.8$. This is consistent with the general altitudes of enhanced backscatter as measured by MPL lidar for this case (Fig. 9c), and also by HSRL for the region on this day (Fig. 10a). The integration of the dry aerosol size distribution measured by the UHSAS provides the aerosol volume concentration shown in Fig. 11b for the same four spiral flights. Similarly, the aerosol volume shows significant increases after cumulus cloud formation from $\sim 1$ to $2.5 \mathrm{~km}$ altitude. This volume concentration increase is due to an increase of the aerosol number concentration from $\sim 1$ to $\sim 1.5 \mathrm{~km}$ and then an increase of the aerosol mean diameter above $1.5 \mathrm{~km}$. Indeed, the aerosol number concentration (from $\sim 1$ to $\sim 1.5 \mathrm{~km}$ ) was on average about $1500 \mathrm{~cm}^{3}$ before the cloud formation and over $2200 \mathrm{~cm}^{3}$ after the cloud formation. The mean geometric diameter values are shifting from $130 \mathrm{~nm}$ below $1.5 \mathrm{~km}$ to $200 \mathrm{~nm}$ above $1.5 \mathrm{~km}$. These results seem to indicate two different process that depend on the localization of the cloud: (1) particle formation and/or redistribution of aerosols below the cloud base leading to an increase of the aerosol concentration (Weigel et al., 2011) and (2) cloud processing of existing aerosols above the cloud base leading to an increase of the aerosol diameter as suggested by Hoppel et al. (1986) and Levin et al. (1996). The analysis of the aerosol chemical composition shows a strong increase of the water-soluble organic carbon (WSOC) by a factor of 2 (up to $6 \mu \mathrm{g} \mathrm{m}^{-3}$ after the cloud formation) within the layer from 1 to $2.5 \mathrm{~km}$. According to previous studies (Blando and Turpin, 2000; Ervens et al., 2011), the formation of SOA through cloud processing is highly plausible. Hennigan et al. (2008) found that the fraction of WSOC in the particle phase increases sharply with RH. The positive correlation with liquid water rather than with organic matter (Hennigan et al., 2009) suggests that aqueous reactions were the dominant SOA formation process rather than gas-phase reactions. Moreover, the inorganic analysis, integrated over a 3-5 min period (limited to few data point per profiles), show an increase by a factor of 1.5 of the sulfate concentration (from $1.6 \mu \mathrm{g} \mathrm{m}^{-3}$ before the cloud formation up to $2.5 \mu \mathrm{g} \mathrm{m}^{-3}$ af ter the cloud formation), while the nitrate concentration do not show any significant evolution. This study case could be used to test the new schemes described by Lim et al. (2010), which take into account the wet processes for SOA formation, and improve numerical models to better take into account the cloud processing products in this particular area.

\subsection{MODIS satellite sensor retrievals of AOD associated with cumulus cloud development}

The multi-angle implementation of atmospheric correction (MAIAC) algorithm (Lyapustin et al., 2011, 2012) was utilized to process MODIS sensor Terra and Aqua satellite data for the $500 \mathrm{~km}$ area that included the DRAGON-2011 campaign domain. MAIAC uses a time series analysis (TMS) approach and processing of pixel groups for simultaneous retrievals of land surface bidirectional reflectance and AOD at high spatial resolution $(1 \mathrm{~km})$. MAIAC also uses TMS to establish characteristic spatial surface reflectance patterns and then subsequently detects clouds based on deviation from this pattern (Lyapustin et al., 2008). The MAIAC cloud mask is enhanced by an additional screening of aerosol retrievals, including filtering of low Ångström exponent values and also a spatial variability test that filters high AOD outliers. The threshold used for this AOD outlier check is a dynamic function of the local cloud fraction. MAIAC also derives the column water vapor from MODIS NIR measurements in the water vapor absorption region of $0.9-0.94 \mu \mathrm{m}$.

The standard MAIAC algorithm was used to process Terra MODIS data (mornings) which were generally cloud-free in the locations of interest. The standard value reported here is a $3 \mathrm{~km} \times 3 \mathrm{~km}$ average, which helps suppress the noise of individual $1 \mathrm{~km}$ retrievals. On the contrary, during the afternoon Aqua overpass the standard algorithm produced no data on 10 July 2011 and 15 July 2013 in locations of interest due to high cumulus cloud fraction. The potential retrievals were filtered by the check for high AOD outliers.

In order to perform TMS data processing, MAIAC originally grids all data to $1 \mathrm{~km}$ resolution. To preserve the spectral content of measurements at equivalent spatial scales, the current gridding procedure first aggregates the higher spatial resolution bands (e.g., 250 and $500 \mathrm{~m}$ ) to $1 \mathrm{~km}$, and then these $1 \mathrm{~km}$ swath data are gridded uniformly along with the 

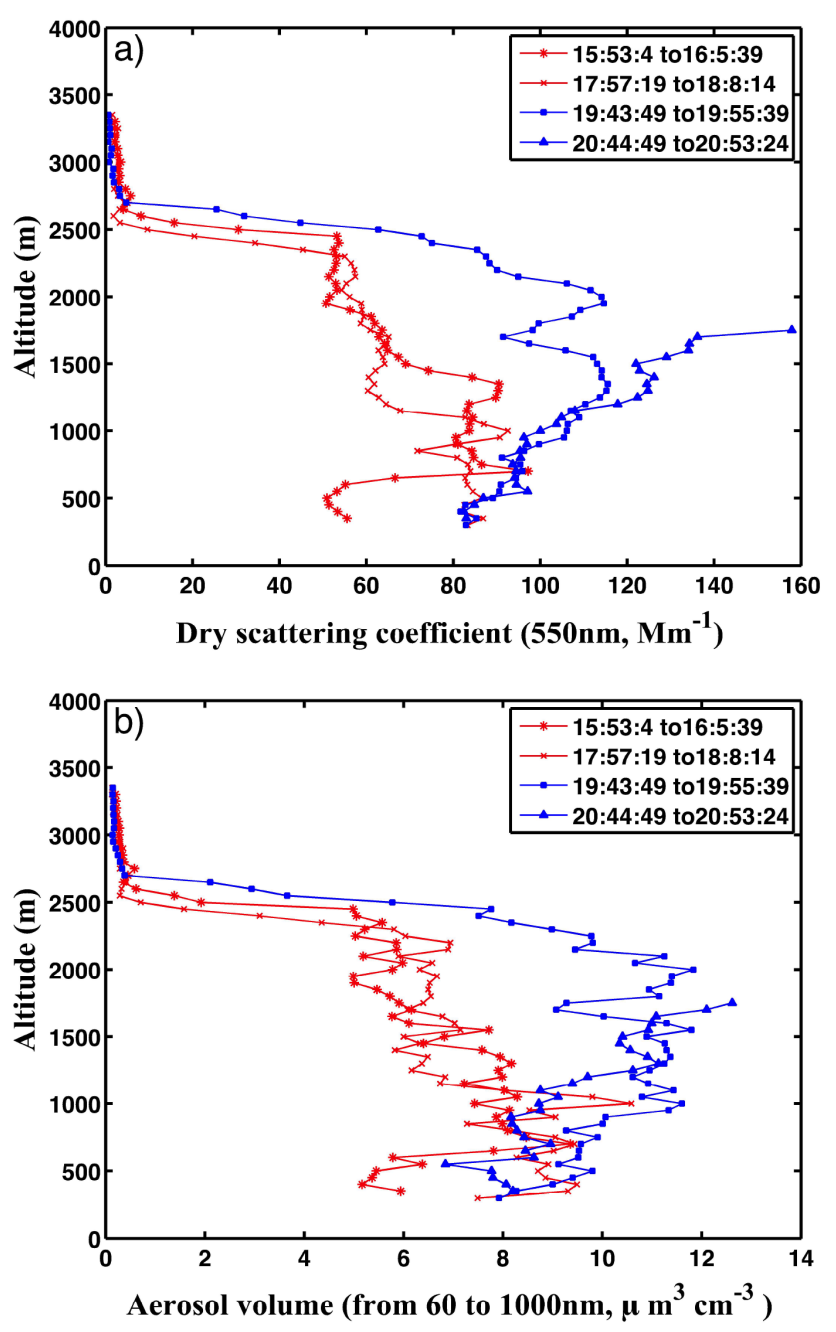

Figure 11. In situ measurements of dry scattering coefficient (a) and aerosol volume (b) from vertical profile flights from the NASA P3-B aircraft made over the DRAGON_Edgewood site on 10 July 2011. Two profile flights made before cumulus formation (in red) and two afterward (blue) are shown. The time series of the AOD and lidar backscatter for this same site and date are shown in Fig. 9c.

native $1 \mathrm{~km}$ bands (e.g., $0.412 \mu \mathrm{m}$ ). This approach effectively reduces the resolution in the blue band $(0.466 \mu \mathrm{m})$ which could be obtained by gridding of the original $500 \mathrm{~m}$ measurements, and may introduce some cloud fraction contamination in clear grid cells adjacent to clouds. These effects often increase retrieved AOD on the border of clouds, which is normally captured by the high AOD outlier filter. For these reasons, we turned off the AOD outlier filter and then output the MAIAC results based on the minimum AOD in each $\pm 3 \mathrm{~km}$ area, yielding afternoon overpass Aqua data for 5 and 10 July 2011 and 15 July 2013.

Presently, 3-D effects are not considered directly in MAIAC retrievals. Indeed, the side-scattering from clouds (usually in the backscattering direction) creates an additional source of radiation which is further scattered into the sen-
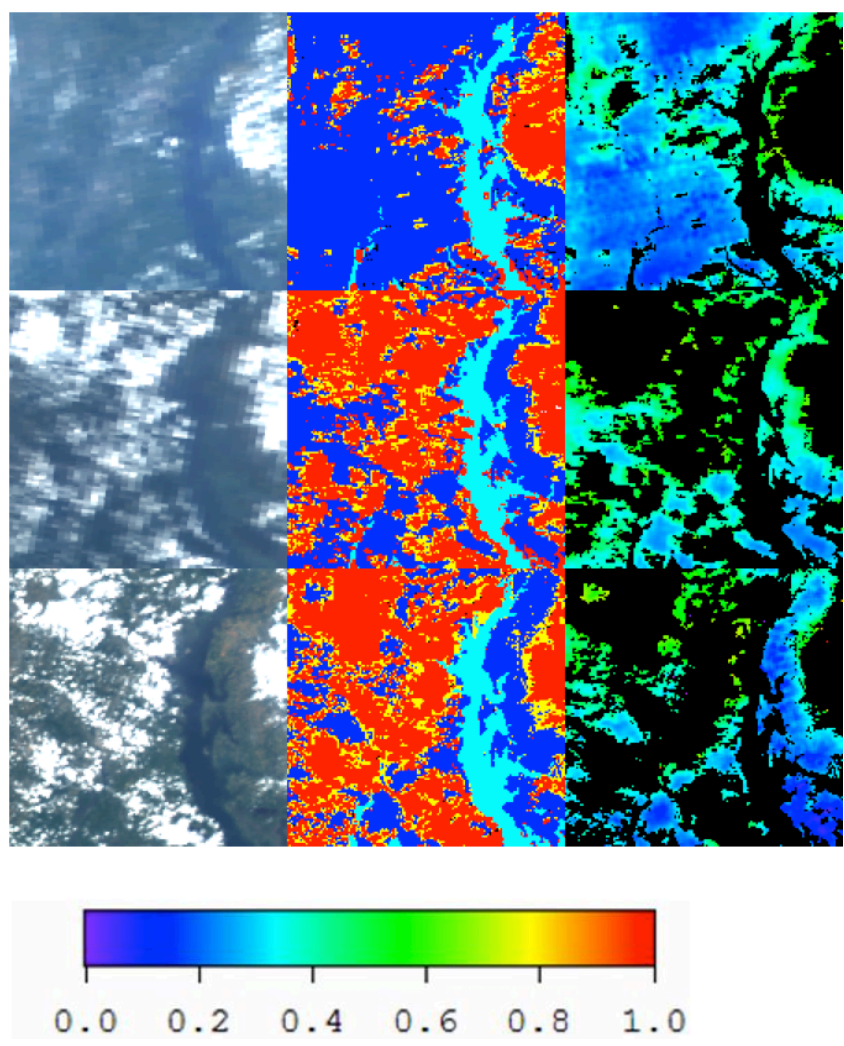

Figure 12. MODIS sensor images of 5 July 2011, Terra overpass at 15:15 UTC (top), Terra overpass at 16:50 UTC (middle), and Aqua overpass at 18:30 UTC (bottom). The top-of-atmosphere (TOA) red-green-blue images (left), cloud masking (middle; red = cloud) and aerosol optical depth (right) are shown. The color scale is for the AOD (right side panels).

sor's field of view mostly by Rayleigh scattering. This effect is noticeable at short wavelengths (e.g., in the blue band) and can increase retrieved AOD. While MAIAC does not directly account for these 3-D effects, it still filters the suspicious cases. The filter is based on the Ångström exponent computed from AOD independently retrieved at 0.47 and $0.66 \mu \mathrm{m}$ over dark surfaces. The 3-D effects would give unrealistically high Ångström exponent values (e.g., above 3.5), which are filtered.

A different type of 3-D effect is frequently observed over brighter surfaces in conditions of broken cloudiness. It is caused by multiple scattering between the surface and clouds, with photons eventually re-directed into the gap between the clouds. In these cases, the red-band enhancement is significantly larger than the blue-band enhancement (in proportion to the surface reflectance), and therefore, such cases produce both enhanced AOD and a very low Ångström exponent typical of dust. Such cases are challenging and we are still working to resolve these in MAIAC retrievals.

In all the cases investigated, the MAIAC algorithm has detected an AOD enhancement that occurred between 

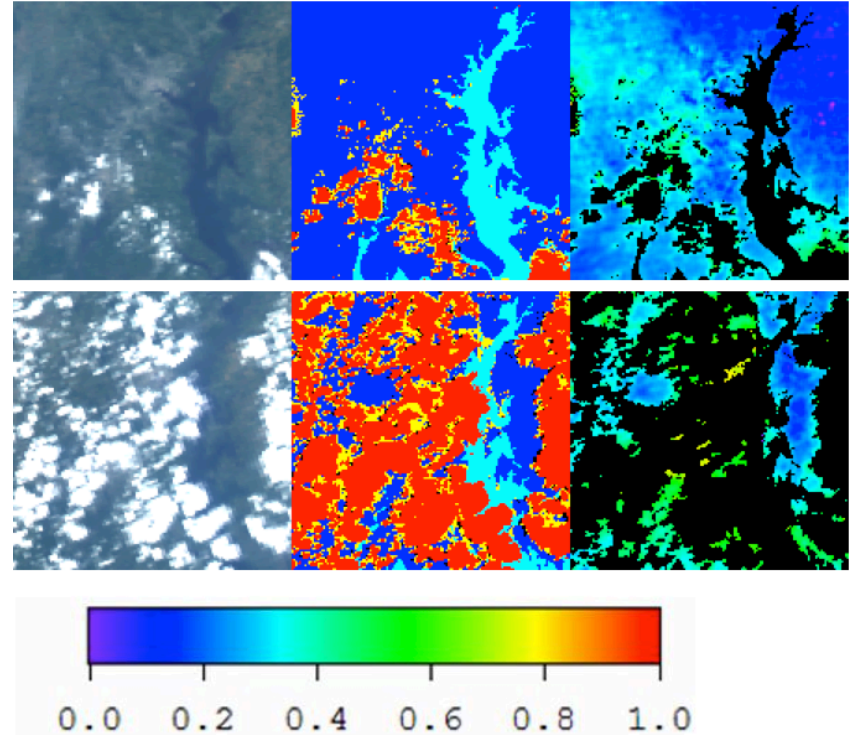

Figure 13. Similar to Fig. 12, but for MODIS sensor images from 10 July 2011, at the Terra overpass time of 15:30 UTC (top) and at Aqua overpass of 18:50 UTC (bottom).

MODIS Terra and Aqua overpasses (morning to afternoon). On 5 July 2011 (Fig. 12) the retrieved Terra overpass (15:15 UTC) AOD of 0.31/0.19 agrees well with AERONET measured AOD interpolated to $0.466 \mu \mathrm{m}(0.35 / 0.21)$ at the Essex/MNKTN site locations, respectively. The standard $3 \mathrm{~km} \times 3 \mathrm{~km}$ average MAIAC afternoon Aqua overpass (18:30 UTC) data are $0.4 / 0.41$ increasing to $0.47 / 0.435$ for retrievals without application of the standard AOD outlier filter. These data fall within the range of AERONET measurements for the same time intervals: for instance, 0.38 (17:11 UTC)-0.54 (19:45 UTC) at Essex, and 0.24 (17:26 UTC)-0.51 (19:11 UTC) at MNKTN.

On 10 July 2011 (Fig. 13), the MAIAC algorithm retrievals showed an AOD increase from 0.25 at 15:30 UTC (Terra) to 0.59 at 18:50 UTC (Aqua) at the Edgewood site, vs. AERONET AOD of 0.265 at $15: 26$ UTC to 0.397 at 18:45 UTC and 0.554 at 19:37 UTC. Note that this is the same site and date of the observed AOD enhancement by MPL lidar and by AERONET measured AOD as shown in Fig. 9. At the GSFC site the Aqua overpass time AOD retrieval from MAIAC was 0.62 at $466 \mathrm{~nm}$, relatively close to the AERONET measured AOD of $\sim 0.56$. This is also an individual case which we examined in detail in Fig. 8, utilizing MPLNET lidar data and AERONET AOD spectra.

Finally, on 15 July 2013 (Fig. 14) at the GSFC site, the MAIAC retrieved Terra AOD is 0.135 (15:30 UTC; the AERONET measured AOD was $\sim 0.11$ ) while Aqua is 0.6 at 18:50 UTC. However, the AERONET measured AOD nearest in time to the afternoon Aqua overpass time, interpolated to $466 \mathrm{~nm}$ was $\sim 0.23$; thus, suggesting that there was significant cloud contamination affecting this particular satellite
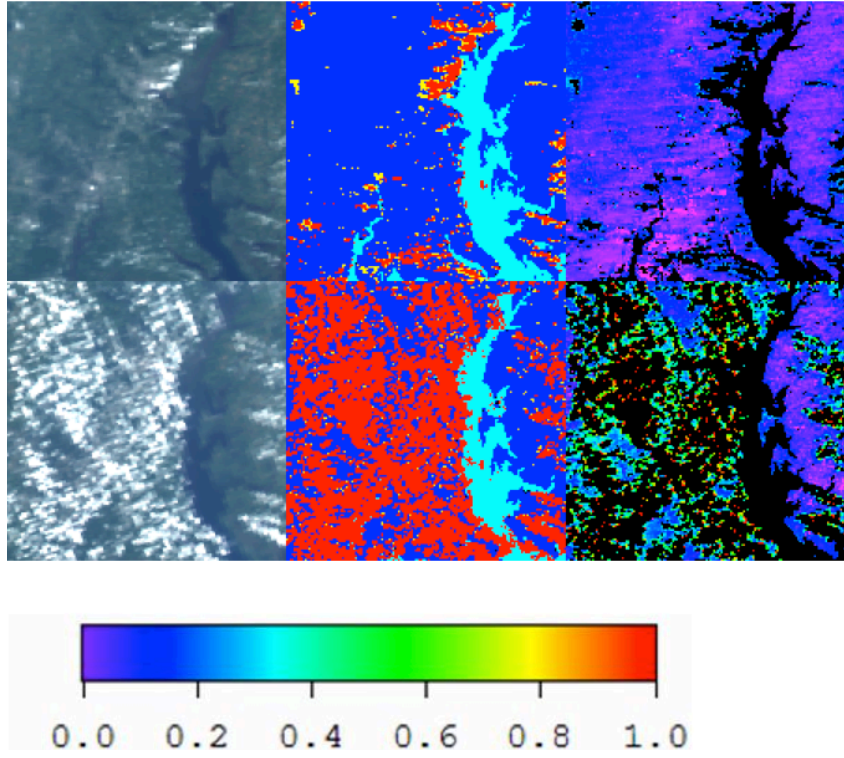

Figure 14. Similar to Fig. 12, but for MODIS sensor images from 15 July 2013, Terra satellite (top) at 15:30 UTC and Aqua satellite (bottom) at 18:50 UTC.

retrieval. In fact the AERONET data exhibit a temporal gap at Aqua overpass time on this day at the GSFC site even for Level 1 data prior to cloud screening, due to clouds obscuring the sun. This example illustrates the difficulty in retrieving AOD from satellite observations when in close proximity to clouds (in this case with non-precipitating cumulus clouds). Retrievals of actual elevated AOD that sometimes occur in close proximity to cumulus cells are also at times mixed with some high AOD retrievals that are cloud contaminated. Although moderate and high-resolution retrievals of AOD provide valuable information, much caution is required in order to interpret passive satellite retrievals of AOD in close proximity to clouds (Zhang et al., 2005; Remer et al., 2013; Munchak et al., 2013).

\section{Discussion}

The long-term monitoring data set at the GSFC site in suburban Maryland, which was within the 2011 DISCOVERAQ regional distribution of sites, provides a climatological context to the phenomenon of the diurnal aspects of cloudaerosol interaction from convective clouds. The GSFC site is the inter-calibration location for the NASA portion of the AERONET federated network. As such, the Cimel sunsky radiometers that are the designated site instruments for the database at GSFC are all calibrated at the high altitude Mauna Loa Observatory (MLO) in Hawaii. The MLO Langley technique calibrations for these reference instruments are highly accurate, resulting in AOD uncertainty of $\sim 0.002$ to $\sim 0.005$ (Eck et al., 1999; Shaw et al., 1983), and these 

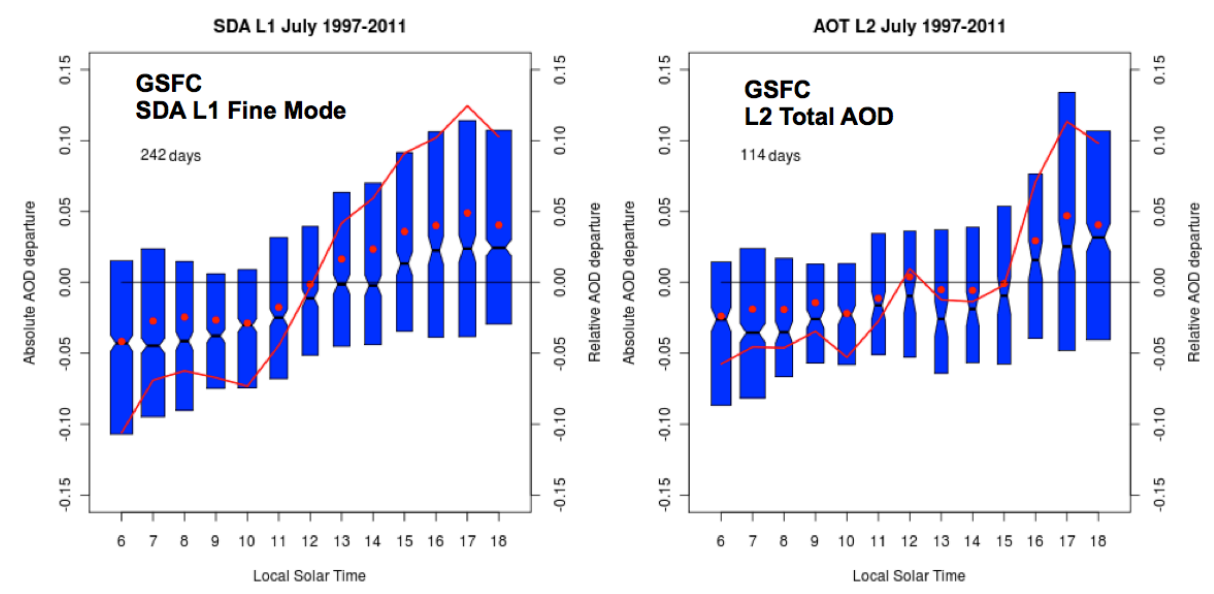

Figure 15. The GSFC site climatology for July (1997-2011) of the hourly absolute AOD departures from the daily mean values. The pinch point on the blue bars are the medians, the upper and lower limits of the blue bars represent the 75th and 25th percentiles, and the width of the bars is proportional to the number of observations in each hour. The red dots are the hourly mean absolute departures and the red line is the relative AOD departure (right side $y$ axis). The left panel shows the analysis for the fine mode AOD without cloud screening (Level 1.0) and the right side panel shows the Level 2 Version 2 cloud screened total AOD.

are the master reference Cimels used for inter-calibration of AERONET field instruments. These small uncertainties in AOD at GSFC result in less uncertainty in AERONET retrievals, both from the SDA algorithm (O'Neill et al., 2003) and the Dubovik algorithm (Dubovik and King, 2000) than at other AERONET sites. Since we are focusing on cloudaerosol interaction in this study, we rely mainly on the SDA retrievals of fine and coarse mode AOD, since good quality sky scan retrievals are typically not feasible in scattered to broken cumulus cloud fields (as discussed previously in Sect. 3.2). This is especially true in close proximity to a cumulus cloud edge, where the maximum enhancements in AOD occur, as inferred from measurements made by HSRL airborne lidar (Sect. 3.4), and since AOD enhancements near $\mathrm{Cu}$ cells result in spatially non-homogeneous aerosol distributions which violate an assumption of relative spatial homogeneity in AOD for the almucantar retrieval.

We focus on the hourly climatological statistics for the month of July (same as the 2011 DISCOVER-AQ Maryland experiment) at the GSFC site, utilizing the data from 1997 through 2011 (15 years). In Fig. 15 we compare the hourly statistics of the Level 1 data of fine mode AOD from SDA, where no cloud screening is applied but final calibration processing is applied, to Level 2 AOD data, where the cloudscreening algorithm of Smirnov et al. (2000) is applied and data have also been quality assured. The blue bars in the figure represent the absolute departures of hourly AOD from the daily mean (left $y$ axis), giving the median value at the pinch point and the 25 th percentile and 75 th percentile values and the top and bottom of the bars. Additionally the widths of these blue bars are proportional to the number of days of hourly observations that are included in the hourly statistic. We have required that there be at least three hourly obser- vations before solar noon and three after solar noon to compute the daily values in order to analyze days with sufficient sampling to characterize the diurnal variation. The red dots in Fig. 15 are the hourly mean absolute departures of AOD from the daily mean, and the red line is the relative fractional AOD departures (right $y$ axis) from the daily mean. First, it is noted that there are more than twice as many days of data included in the Level 1 analysis (242 days) as for the cloud screened Level 2 (114 days). The same analysis but with the criteria of only $1 \mathrm{~h}$ of data required both before and after solar noon resulted in only $\sim 20 \%$ less days of data for the Level 2 analysis compared to Level 1, but with nearly identical looking data as Fig. 15. The widths of the blue bars denoting data density show much less variation across the diurnal cycle for the Level 1 data than Level 2 due to relatively much more cloud screening of data in Level 2 from near noon through most of the afternoon when cumulus are most likely to develop. The non-cloud-screened fine mode AOD exhibits smooth hourly increases in AOD from the morning to the afternoon, as compared to the cloud screened Level 2 AOD that shows a slight increase followed by a decrease in the midafternoon and sharp increase in late afternoon. We argue that the diurnal trend in the Level 1 fine mode AOD results from the cumulus cloud convective cycle and the AOD enhancements associated with these clouds. In contrast, the slight decrease and relatively flat AOD in mid-afternoon in the Level 2 AOD results from the cloud screening of the data near to clouds from larger triplets in this dynamic near-cloud environment yet still large Ångström exponents. We show individual day and site examples of this in Fig. 16 for two sites in the DISCOVER-AQ campaign in July 2011. The sparseness of Level 2 data in the afternoon is contrasted with numerous Level 1 AOD measurements in the afternoon in both cases. 

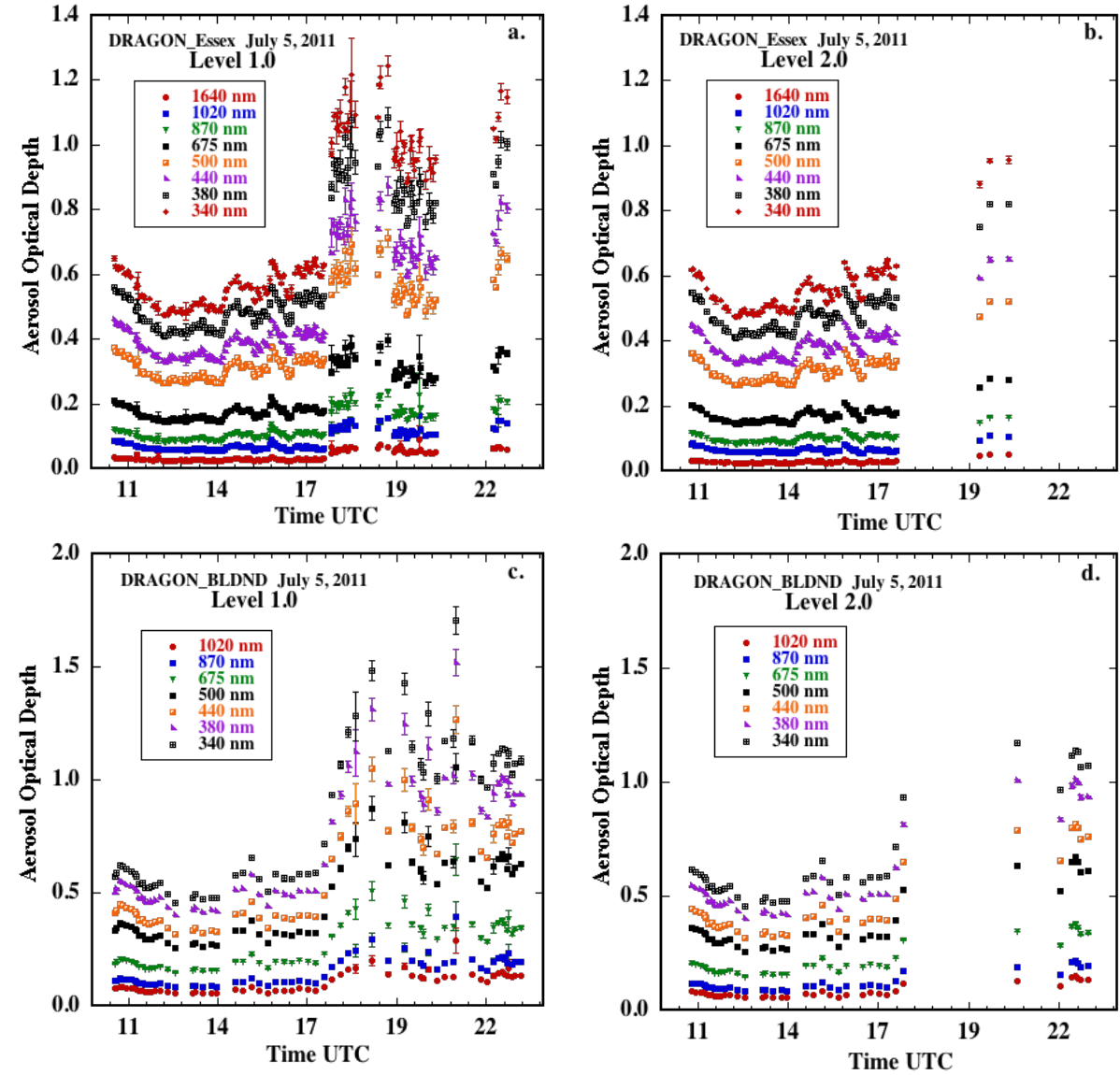

Figure 16. Examples of non-cloud-screened (Level 1) vs. Level 2 Version 2 cloud screened AOD time series for the DRAGON_Essex (a) and (b) and DRAGON_BLDND sites (c) and (d) in Maryland on 5 July 2011.

Similarly, both cases where almucantar retrieval analysis was presented in Sect. 3.2 also show larger triplet AOD observations in mid-afternoon that exceed the Version 2 cloudscreening thresholds for AOD variability in a one minute interval. This tendency of eliminating the AOD associated with convective clouds during some afternoon time intervals likely results in the Level 2 data set being weighted more towards lower AOD days when cumulus clouds do not develop. In support of this hypothesis we present a simpler analysis of diurnal hourly fine mode AOD in Fig. 17, where AOD averages are computed for each hour and Level 1 and Level 2 fine mode AOD compared. This analysis uses data from the three-month summer season (June through August) at GSFC for the same 15-year interval as shown in Fig. 15. The differences in the Level 1 vs. Level 2 fine mode AOD are only $\sim 0.01$ in the early morning; however, the differences start increasing at one hour before solar noon and reach the maximum differences of $\sim 0.07$ to $\sim 0.08$ at one to three hours after solar noon. Again these much higher Level 1 fine AOD in the afternoon coincide with the timing of the diurnal convective cloud cycle associated with fair weather (nonprecipitating) cumulus clouds, and the elimination of higher
AOD near cumulus cells in the Level 2 data, largely due to larger high frequency AOD variation (larger AOD triplets). It is noted that there is no significant diurnal trend in Angström exponent (440-870 nm) from hours 9 through 16 local hours (range of only $\sim 0.02$ ) for both the Level 1 or Level 2 data, thus strongly suggesting that these diurnal patterns are not significantly affected by cloud contamination. These analyses therefore suggest that the diurnal cycle AOD investigations based on Level 2 AERONET data in both Smirnov et al. (2002) and Zhang et al. (2012) have not taken into account the effects of cumulus cloud influences on AOD in this region in summer, and therefore missed a part of the true diurnal cycle of AOD. We note that the future AERONET Version 3 cloud-screening algorithm will allow more AOD observations in the near-cumulus cloud environment, primarily since only the AOD at longer wavelengths $(675,870$ and $1020 \mathrm{~nm}$ ) will be checked for triplet variability and in these fine mode dominated cases both the AOD and its variation is significantly smaller for these wavelengths than the short wavelength visible and the ultraviolet ( 340 and $380 \mathrm{~nm}$ ). 
GSFC JJA 1997-2011

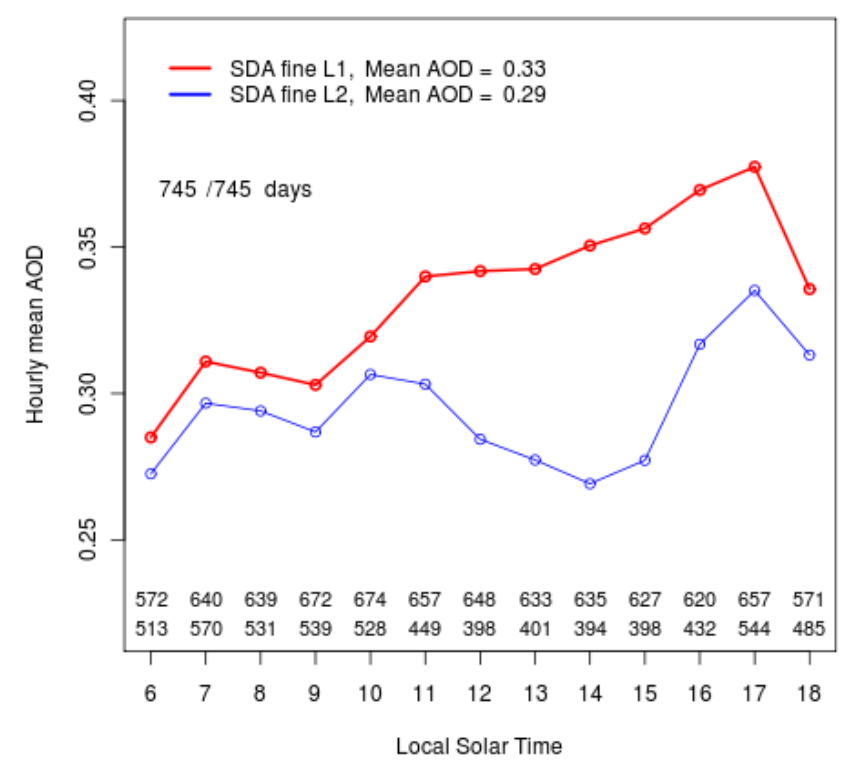

Figure 17. Hourly mean fine mode AOD for the GSFC site climatology (1997-2011) for the summer months (June through August). The red line shows data with no cloud screening (Level 1) compared to the blue line with cloud screened data (Level 2 Version 2). A total of 745 days were analyzed, with the values above the $x$ axis showing the number of days for each hour, with the upper numbers for the Level 1 data and the lower for the Level 2 data.

\section{Conclusions}

1. Direct sun measurements of AOD at several AERONET sites during the DISCOVER-AQ field campaign in Maryland during July 2011 have shown large enhancements in fine mode AOD associated with the timing of the diurnal convective cycle of fair weather cumulus clouds. The large increases in AOD (doubling at times) in proximity to larger cumulus cells can sometimes be very rapid, within minutes of cumulus development. These relatively high AOD close to cumulus cloud edges typically exhibit high frequency variability possibly resulting from the turbulent environment in the immediate vicinity of convective cells.

2. Both AERONET almucantar size distribution retrievals and time series of Ångström exponents from before, during and after cumulus cloud development suggest in some cases a slight increase in fine mode particle radius, and in others no significant change in fine mode particle size. This implies possible new particle formation and/or humidification of sub-visible-sized (Aitken) particles into the accumulation mode size range (optically effective) in addition to existing particle growth by humidification and/or cloud processing. Several in situ measurement and modeling studies in the recent literature have found significant new particle formation from aqueous-phase chemistry within cumulus clouds including sulfates, nitrates and secondary organic aerosols.

3. In situ measurements made from aircraft in a vertical spiral profile over an AERONET ground site on one day during DISCOVER-AQ showed very large increases aloft in aerosol scattering coefficient and aerosol volume after cumulus cloud development as compared to before cloud formation. This was consistent with ground-based AOD measurements that showed very large increases (a factor of 2 to 3 ) after cumulus development, at this same site and date.

4. During the DISCOVER-AQ campaign, both MPL and HSRL lidar measured significant increases in attenuated backscatter and backscatter coefficients coincident with cumulus development times, and at altitudes corresponding to cumulus cloud height and somewhat below the cloud base. These data suggest that cumulus clouds in summer may at times result in significant modification of the aerosol vertical profile, at least temporarily creating an enhanced aerosol layer in the upper half of the mixed layer.

5. Airborne HSRL downward viewing lidar enabled the quantification of the spatial extent of aerosol enhancements in the immediate vicinity of cumulus clouds on one day during the DISCOVER-AQ experiment. Enhancements in AOD in the immediate vicinity of cumulus clouds averaged $25 \%$ when comparing data close to cloud edge vs. measurements taken $2.5 \mathrm{~km}$ from the clouds. Additionally, average backscatter and extinction at cumulus altitudes ( $\sim 2$ to $2.5 \mathrm{~km}$ ) increased by $\sim 50$ $60 \%$ near to cloud vs. $\sim 2.5 \mathrm{~km}$ distant from the cloud edge.

6. Fifteen years of monitoring by sun-sky radiometers at the AERONET site at GSFC enabled a climatological perspective of the diurnal variation of AOD in summer. Analysis of the fine mode AOD component from the SDA algorithm suggests significant enhancements in AOD from the late morning to late afternoon, corresponding to the timing of the convective cycle that results in formation of fair weather cumulus clouds. The three-month June through August seasonal average AOD (computed from daily means) at GSFC is $\sim 10 \%$ higher when allowing these high temporal variance AOD observations (mainly associated with cumulus clouds) as opposed to the cloud screened (Level 2) Version 2 AOD. Due to the difficulty in passive satellite remote sensing of aerosols in close proximity to clouds, it is likely that satellite estimates of AOD may also be underestimated in cumulus cloud regimes. 
The remote-sensing and in situ data sets acquired during the DISCOVER-AQ campaign in Maryland in July 2011, and analyzed in the paper, may potentially provide valuable case studies of observations for comparison to modeling of cumulus-aerosol interactions.

Acknowledgements. The AERONET project was supported by Michael D. King, retired in 2008 from the NASA EOS project office, and by Hal B. Maring, Radiation Sciences Program, NASA Headquarters. Sigma Space and Penn State are acknowledged for loan and site hosting, respectively, of the Mini-MPL at the Edgewood site. Funding for Mini-MPL work was provided by NASA DISCOVER-AQ mission to facilitate field work and data processing.

Edited by: P. Formenti

\section{References}

Ackermann, J.: The extinction-to-backscatter ratio of tropospheric aerosol: A numerical study, J. Atmos. Ocean. Tech., 15, 1043-1050, doi:10.1175/15200426(1998)015<1043:TETBRO>2.0.CO;2, 1998.

Anderson, T. L. and Ogren, J.A.: Determining aerosol radiative properties using the TSI 3563 integrating nephelometer, Aerosol Sci. Tech., 29, 57-69, doi:10.1080/02786829808965551, 1998.

Berkoff, T., Hoff, R. M., Delgado, R., Sullivan, J., Thomas, A., Lawrence, W. T., Jones, T., Decola, P., Mathur, S., Zheng, Y., Wyant, G. J., Blucher, R. G., Piatt, R., Abderrahman, M., Martins, D. K., Auvil, R., Woodman, M., Connell, R., Hicks, M., Venable,D. D., Demoz, B., Tzortziou, M., De Rosa, P. J., Pickering, K. E., Starr, D., Welton, E. J., Holben, B. N., Ferrare, R. A., Hostetler, C. A., and Crawford, J. H.: Field deployment and initial results from micro-pulse lidar systems during NASA's DISCOVER AQ campaign, American Geophysical Union, Fall Meeting Abstracts, 2012.

Blando, J. D. and Turpin, B. J.: Secondary organic aerosol formation in cloud and fog droplets: a literature evaluation of plausibility, Atmos. Environ., 34, 1623-1632, doi:10.1016/S13522310(99)00392-1, 2000.

Burton, S. P., Ferrare, R. A., Hostetler, C. A., Hair, J. W., Kittaka, C., Vaughan, M. A., Obland, M. D., Rogers, R. R., Cook, A. L., Harper, D. B., and Remer, L. A.: Using airborne high spectral resolution lidar data to evaluate combined active plus passive retrievals of aerosol extinction profiles, J. Geophys. Res.-Atmos., 115, D00H15, doi:10.1029/2009JD012130, 2010.

Burton, S. P., Ferrare, R. A., Vaughan, M. A., Omar, A. H., Rogers, R. R., Hostetler, C. A., and Hair, J. W.: Aerosol classification from airborne HSRL and comparisons with the CALIPSO vertical feature mask, Atmos. Meas. Tech., 6, 13971412, doi:10.5194/amt-6-1397-2013, 2013.

Carrico, C. M., Rood, M. J., and Ogren, J. A.: Aerosol light scattering properties at Cape Grim, Tasmania, during the First Aerosol Characterization Experiment (ACE 1), J. Geophys. Res., 103, 16565-16574, doi:10.1029/98JD00685, 1998.

Chew, B. N., Campbell, J. R., Reid, J. S., Giles, D. M., Welton, E. J., Salinas, S. V., and Liew, S. C.: Tropical cirrus cloud contami- nation in sun photometer data, Atmos. Environ., 45, 6724-6731, doi:10.1016/j.atmosenv.2011.08.017, 2011.

Clarke, A. D., Howell, S., Quinn, P. K., Bates, T. S., Ogren, J. A., Andrews, E., Jefferson, A., Massling, A., Mayol Bracero, O., Maring, H., Savoie, D., and Cass, G.: INDOEX aerosol: A comparison and summary of chemical, microphysical, and optical properties observed from land, ship, and aircraft, J. Geophys. Res., 107, 8033, doi:10.1029/2001JD000572, 2002.

Crumeyrolle, S., Chen, G., Ziemba, L., Beyersdorf, A., Thornhill, L., Winstead, E., Moore, R. H., Shook, M. A., Hudgins, C., and Anderson, B. E.: Factors that influence surface $\mathrm{PM}_{2.5}$ values inferred from satellite observations: perspective gained for the US Baltimore-Washington metropolitan area during DISCOVERAQ, Atmos. Chem. Phys., 14, 2139-2153, doi:10.5194/acp-142139-2014, 2014.

Dubovik, O. and King, M. D.: A flexible inversion algorithm for the retrieval of aerosol optical properties from Sun and sky radiance measurements, J. Geophys. Res., 105, 20673-20696, 2000.

Dubovik, O., Smirnov, A., Holben, B. N., King, M. D., Kaufman, Y. J., Eck, T. F., and Slutsker, I.: Accuracy assessments of aerosol optical properties retrieved from AERONET Sun and sky-radiance measurements, J. Geophys. Res., 105, 9791-9806, 2000.

Dubovik, O., Sinyuk, A., Lapyonok, T., Holben, B. N., Mishchenko, M., Yang, P., Eck, T. F., Volten, H., Mũnoz, O., Veihelmann, B., van der Zande, W. J., Leon, J.-F., Sorokin, M., and Slutsker, I.: The application of spheroid models to account for aerosol particle nonsphericity in remote sensing of desert dust, J. Geophys. Res., 111, D11208, doi:10.1029/2005JD006619, 2006.

Eck, T. F., Holben, B. N., Reid, J. S., Dubovik, O., Smirnov, A., O'Neill, N. T., Slutsker, I., and Kinne, S.: Wavelength dependence of the optical depth of biomass burning, urban, and desert dust aerosols, J. Geophys. Res., 104, 31333-31349, 1999.

Eck, T. F., Holben, B. N., Ward, D. E., Dubovik, O., Reid, J. S., Smirnov, A., Mukelabai, M. M., Hsu, N. C., O’Neill, N. T., and Slutsker, I.: Characterization of the optical properties of biomass burning aerosols in Zambia during the 1997 ZIBBEE Field Campaign, J. Geophys. Res., 106, 3425-3448, 2001.

Eck, T. F., Holben, B. N., Reid, J. S., Sinyuk, A., Dubovik, O., Smirnov, A., Giles, D., O’Neill, N. T., Tsay, S.-C., Ji, Q., Mandoos, A. A., Khan, M. R., Reid, E. A., Schafer, J. S., Sorokine, M., Newcomb, W., and Slutsker, I.: Spatial and temporal variability of column-integrated aerosol optical properties in the southern Arabian Gulf and United Arab Emirates in summer, J. Geophys. Res., 113, D01204, doi:10.1029/2007JD008944, 2008.

Eck, T. F., Holben, B. N., Sinyuk, A., Pinker, R. T., Goloub, P., Chen, H., Chatenet, B., Li, Z., Singh, R. P., Tripathi, S. N., Reid, J. S., Giles, D. M., Dubovik, O., O'Neill, N. T., Smirnov, A., Wang, P., and Xia, X.: Climatological aspects of the optical properties of fine/coarse mode aerosol mixtures, J. Geophys. Res., 115, D19205, doi:10.1029/2010JD014002, 2010.

Eck, T. F., Holben, B. N., Reid, J. S., Giles, D. M., Rivas, M. A., Singh, R. P., Tripathi, S. N., Bruegge, C. J., Platnick, S., Arnold, G. T., Krotkov, N. A., Carn, S. A., Sinyuk, A., Dubovik, O., Arola, A., Schafer, J. S., Artaxo, P., Smirnov, A., Chen, H., and Goloub, P.: Fog- and cloud-induced aerosol modification observed by the Aerosol Robotic Network (AERONET), J. Geophys. Res., 117, D07206, doi:10.1029/2011JD016839, 2012. 
Ervens, B., Turpin, B. J., and Weber, R. J.: Secondary organic aerosol formation in cloud droplets and aqueous particles (aqSOA): a review of laboratory, field and model studies, Atmos. Chem. Phys., 11, 11069-11102, doi:10.5194/acp-1111069-2011, 2011.

Fernald, F. G.: Analysis of atmospheric lidar observations: some comments, Appl. Opt., 23, 652-653, 1984.

Ferrare, R., Clayton, M., Turner, D., Hostetler, C., Hair, J., Obland, M., Rogers, R., Swanson, A., Jefferson, A., and Jonsson, H.: Raman lidar and HSRL measurements of aerosol and water vapor variability, in Dept. of Energy (DOE) Atmospheric Systems Research (ASR) Science Team Meeting, San Antonio, TX, http://asr.science.energy.gov/publications/ program-docs/doe-sc-asr-11-002.pdf, 2011.

Ford, B. and Heald, C. L.: Aerosol loading in the Southeastern United States: reconciling surface and satellite observations, Atmos. Chem. Phys., 13, 9269-9283, doi:10.5194/acp-13-92692013, 2013.

Grund, C. J. and Eloranta, E. W.: University of Wisconsin High Spectral Resolution Lidar, Opt. Eng., 30, 6-12, doi:10.1117/12.55766, 1991.

Hair, J. W., Hostetler, C. A., Cook, A. L., Harper, D. B., Ferrare, R. A., Mack, T. L., Welch, W., Izquierdo, L. R., and . Hovis, F. E: Airborne high spectral resolution lidar for profiling aerosol optical properties, Appl. Opt., 47, 6734-6752, doi:10.1364/AO.47.006734, 2008.

Hansen, A. D. A., Benner, W. H., and Novakov, T.: Sulfur-dioxide oxidation in laboratory clouds, Atmos. Environ., Part A-General Topics, 25, 2521-2530, doi:10.1016/0960-1686(91)90168-7, 1991.

Hayden, K. L., Macdonald, A. M., Gong, W., Toom-Sauntry, D., Anlauf, K. G., Leithead, A., Li, S.-M., Leaitch, W. R., and Noone, K.: Cloud processing of nitrate, J. Geophys. Res., 113, D18201, doi:10.1029/2007JD009732, 2008.

Hennigan, C. J., Bergin, M. H., Dibb, J. E., and Weber, R. J.: Enhanced secondary organic aerosol formation due to water uptake by fine particles, Geophys. Res. Lett., 35, L18801, doi:10.1029/2008GL035046, 2008.

Hennigan, C. J., Bergin, M. H., Russell, A. G., Nenes, A., and Weber, R. J.: Gas/particle partitioning of water-soluble organic aerosol in Atlanta, Atmos. Chem. Phys., 9, 3613-3628, doi:10.5194/acp-9-3613-2009, 2009.

Holben, B. N., Eck, T. F., Slutsker, I., Tanre, D., Buis, J. P., Setzer, A., Vermote, E., Reagan, J. A., Kaufman, Y., Nakajima, T., Lavenu, F., Jankowiak, I., and Smirnov, A.: AERONET-A federated instrument network and data archive for aerosol characterization, Remote Sens. Environ., 66, 1-16, 1998.

Holben, B., Tanre, D., Smirnov, A., Eck, T., Slutsker, I., Abuhassan, N., Newcomb, W. W., Schafer, J., Chatenet, B., Lavenue, F., Kaufman, Y., Castle, J. V., Setzer, A., Markham, B., Clark, D., Frouin, R., Halthore, R., Karnieli, A., O’Neill, N., Pietras, C., Pinker, R., Voss, K., and Zibordi, G.: An emerging ground-based aerosol climatology: Aerosol Optical Depth from AERONET, J. Geophys. Res., 106, 12067-12097, 2001.

Holben, B. N., Eck, T. F., Slutsker, I., Smirnov, A., Sinyuk, A., Schafer, J., Giles,D., and Dubovik, O.: AERONET's version 2.0 quality assurance criteria, Remote Sensing of Atmosphere and Clouds, Proc. SPIE Int. Soc. Opt. Eng., 6408, 64080Q, doi:10.1117/12.706524, 2006.
Hoppel, W. A., Frick, G. M., and Larson, R. E.: Effects on nonprecipitating clouds on the aerosol size distribution in the marine boundary layer, Geophys. Res. Lett., 13, 125-128, 1986.

Ignatov, A., Minnis, P., Loeb, N., Wielicki, B., Miller, W., SunMack, S., Tanre, D., Remer, L., Laslo, I., and Geier, E.: Two MODIS aerosol products over ocean on the Terra and Aqua CERES SSF., J. Atmos. Sci., 62, 1008-1031, 2005.

Jeong, M.-J. and Z. Li: Separating real and apparent effects of cloud, humidity, and dynamics on aerosol optical thickness near cloud edges, J. Geophys. Res., 115, D00K32, doi:10.1029/2009JD013547, 2010.

Jiménez-Escalona, J. C. and Peralta, O.: Processing of aerosol particles in convective cumulus clouds: Cases study in the Mexican East Pacific. Adv. Atmos. Sci., 27, 1331-1343, doi:10.1007/s00376-010-9114-3, 2010.

Johnson B. T. and Osborne S. R.: Physical and optical properties of mineral dust aerosol measured by aircraft during the GERBILS campaign, Q. J. Roy. Meteor. Soc., 137, 1117-1130, doi:10.1002/qj.777, 2011.

Kaku, K. C., Reid, J. S., O’Neill, N. T., Quinn, P. K., Coffman, D. J., and Eck, T. F.: Verification and application of the extended spectral deconvolution algorithm (SDA+) methodology to estimate aerosol fine and coarse mode extinction coefficients in the marine boundary layer, Atmos. Meas. Tech., 7, 3399-3412, doi:10.5194/amt-7-3399-2014, 2014.

Kasten, F.: Visibility forecast in the phase of pre-condensation, Tellus, 21, 631-635, doi:10.1111/j.2153-3490.1969.tb00469.x, 1969.

Kaufman, Y. J. and Fraser, R. S.: The effect of smoke particles on clouds and climate forcing, Science, 277, 5332, 1636-1639, 1997.

Kinne, S., Ackerman, T. P., Shiobara, M., Uchiyama, A., Heymsfield, A. J., Miloshevich, L., Wendell, J., Eloranta, E. W., Purgold, C., and Bergstrom, R. W.: Cirrus cloud radiative and microphysical properties from ground observations and in situ maesurements during FIRE 1991 and their application to exhibit problems in cirrus solar radiative transfer modeling, J. Atmos. Sci., 54, 2320-2344, 1997.

Lelieveld, J. and Heintzenberg, J.: Sulfate Cooling Effect on Climate Through In-Cloud Oxidation of Anthropogenic $\mathrm{SO}_{2}$, Science, 258, 117-120, 1992.

Levin, Z., Ganor, E., and Gladstein, V.: The effects of desert particles coated with sulfate on rain formation in the eastern mediterranean, J. Appl. Meteorol., 35, 1511-1523, 1996.

Lim, Y. B., Tan, Y., Perri, M. J., Seitzinger, S. P., and Turpin, B. J.: Aqueous chemistry and its role in secondary organic aerosol (SOA) formation, Atmos. Chem. Phys., 10, 1052110539, doi:10.5194/acp-10-10521-2010, 2010.

Loughner, C. P., Allen, D. J., Pickering, K. E., Zhang, D.-L., Shou, Y.-X., and Dickerson, R. R.: Impact of fair-weather cumulus clouds and the Chesapeake Bay breeze on pollutant transport and transformation, Atmos. Environ., 45, 4060-4072, doi:10.1016/j.atmosenv.2011.04.003, 2011.

Lu, M.-L., Jian, W., Flagan, R. C., Seinfeld, J. H., Freedman, A., McClatchey, R. A. and Jonsson, H. H. : Analysis of Humidity Halos around Trade Wind Cumulus Clouds, J. Atmos. Sci., 60, 1041-1059, 2003. 
Lyapustin, A., Wang, Y., and Frey, R.: An automatic cloud mask algorithm based on time series of MODIS measurements, J. Geophys. Res., 113, D16207, doi:10.1029/2007JD009641, 2008.

Lyapustin, A., Wang, Y., Laszlo, I., Kahn, R., Korkin, S., Remer, L., Levy, R., and Reid, J. S.: Multiangle implementation of atmospheric correction (MAIAC): 2. Aerosol algorithm, J. Geophys. Res., 116, D03211, doi:10.1029/2010JD014986, 2011.

Lyapustin, A., Wang, Y., Laszlo, I., and Korkin, S.: Improved cloud and snow screening in MAIAC aerosol retrievals using spectral and spatial analysis, Atmos. Meas. Tech., 5, 843-850, doi:10.5194/amt-5-843-2012, 2012.

Marenco, F., Santacesaria, V., Bais, A. F., Balis, D., di Sarra, A., Papayannis, A., and Zerefos, C.: Optical properties of tropospheric aerosols determined by lidar and spectrophotometric measurements (Photochemical Activity and Solar Ultraviolet Radiation campaign), Appl. Opt., 36, 6875-6886, 1997.

Marshak, A., Wen, G., Coakley Jr., J. A., Remer, L. A., Loeb, N. G., and Cahalan, R. F.: A simple model for the cloud adjacency effect and the apparent bluing of aerosols near clouds, J. Geophys. Res. 113, D14S17, doi:10.1029/2007JD009196, 2008.

McNaughton, C. S., Clarke, A. D., Howell, S. G., Pinkerton, M., Anderson, B., Thornhill, L., Hudgins, C., Winstead, E., Dibb, J. E., Scheuer, E., and Maring, H.: Results from the DC-8 Inlet Characterization Experiment (DICE): Airborne versus surface sampling of mineral dust and sea salt aerosols, Aerosol Sci. Tech., 41, 136-159, doi:10.1080/02786820601118406, 2007.

Müller, D., Ansmann, A., Mattis, I., Tesche, M., Wandinger, U., Althausen, D., and Pisani, G.: Aerosol-type-dependent lidar ratios observed with Raman lidar, J. Geophys. Res., 112, D16202, doi:10.1029/2006JD008292, 2007.

Murayama, T., Furushima, M., Oda, A., and Iwasaka, N.: Depolarization ratio measurements in the atmospheric boundary layer by lidar in Tokyo, J. Meteorological Soc. of Japan, 74, 571-578, 1996.

Munchak, L. A., Levy, R. C., Mattoo, S., Remer, L. A., Holben, B. N., Schafer, J. S., Hostetler, C. A., and Ferrare, R. A.: MODIS $3 \mathrm{~km}$ aerosol product: applications over land in an urban/suburban region, Atmos. Meas. Tech., 6, 1747-1759, doi:10.5194/amt-6-1747-2013, 2013.

O’Neill, N. T., Eck, T. F., Holben, B. N., Smirnov, A., Dubovik, O., and Royer, A.: Bimodal size distribution influences on the variation of Angstrom derivatives in spectral and optical depth space, J. Geophys. Res., 106, 9787-9806, 2001.

O’Neill, N. T., Eck, T. F., Smirnov, A., Holben, B. N., and Thulasiraman, S.: Spectral discrimination of coarse and fine mode optical deph, J. Geophys. Res., 108, 4559, doi:10.1029/2002JD002975, 2003.

Pueschel, R. F., Russell, P. B., Allen, D. A., Ferry, G. V., Snetsinger, K. G., Livingston, J. M., and Verma, S.: Physical and optical properties of the Pinatubo volcanic aerosol: Aircraft observations with impactors and a Sun-tracking photometer, J. Geophys. Res., 99, 12915-12922, 1994.

Radke, L. F. and Hobbs, P. V.: Humidity and Particle Fields Around Some Small Cumulus Clouds, J. Atmos. Sci., 48, 1190-1193, doi:10.1175/1520-0469(1991)048<1190:HAPFAS>2.0.CO;2, 1991.

Reid, J. S., Eck, T. F., Christopher, S. A., Hobbs, P. V., and Holben, B. N.: Use of the Angstrom exponent to estimate the variabil- ity of optical and physical properties of aging smoke particles in Brazil, J. Geophys. Res., 104, 27473-27489, 1999.

Reid, J. S., Koppmann, R., Eck, T. F., and Eleuterio, D. P.: A review of biomass burning emissions part II: intensive physical properties of biomass burning particles, Atmos. Chem. Phys., 5, 799825, doi:10.5194/acp-5-799-2005, 2005.

Reid, J. S., Brooks, B., Crahan, K. K., Hegg, D. A., Eck, T. F., O'Neill, N., de Leeuw, G., Reid, E. A., and Anderson, K. D.: Reconciliation of coarse mode sea-salt aerosol particle size measurements and parameterizations at a subtropical ocean receptor site, J. Geophys. Res., 111, D02202, doi:10.1029/2005JD006200, 2006.

Reid, J. S., Reid, E. A., Walker, A., Piketh, S., Cliff, S., Al Mandoos, A., Tsay, S.-C., and Eck, T. F.: Dynamics of southwest Asian dust particle size characteristics with implications for global dust research, J. Geophys. Res., 113, D14212, doi:10.1029/2007JD009752, 2008.

Reid, J. S., Hyer, E. J., Johnson, R. S., Holben, B. N., Yokelson, R. J., Zhang, J., Campbell, J. R., Christopher, S. A., Di Girolamo, L., Giglio, L., Holz, R. E., Kearney, C., Miettinen, J., Reid, E. A., Turk, F. J., Wang, J., Xian, P., Zhao, G., Balasubramanian, R., Chew, B. N., Janjai, S., Lagrosas, N., Lestari, P., Lin, N.H., Mahmud, M., Nguyen, A. X., Norris, B., Oanh, N. T. K., Oo, M., Salinas, S. V., Welton, E. J. and Liew, S. C.: Observing and understanding the Southeast Asian aerosol system by remote sensing: An initial review and analysis for the Seven Southeast Asian Studies (7SEAS) program, Atmos. Res., 122, 403-468, doi:10.1016/j.atmosres.2012.06.005, 2013.

Remer, L. A., Mattoo, S., Levy, R. C., and Munchak, L. A.: MODIS $3 \mathrm{~km}$ aerosol product: algorithm and global perspective, Atmos. Meas. Tech., 6, 1829-1844, doi:10.5194/amt-6-1829-2013, 2013.

Rogers, R. R., Hair, J. W., Hostetler, C. A., Ferrare, R. A., Obland, M. D., Cook, A. L., Harper, D. B., Burton, S. P., Shinozuka, Y., McNaughton, C. S., Clarke, A. D., Redemann, J., Russell, P. B., Livingston, J. M., and Kleinman, L. I.: NASA LaRC airborne high spectral resolution lidar aerosol measurements during MILAGRO: observations and validation, Atmos. Chem. Phys., 9, 4811-4826, doi:10.5194/acp-9-4811-2009, 2009.

Sasano, Y. and Browell, E. V.: Light-Scattering Characteristics Of Various Aerosol Types Derived From Multiple Wavelength Lidar Observations, Appl. Optics, 28, 1670-1679, 1989.

Sassen, K.: Lidar backscatter depolarization technique for cloud and aerosol research, in: Light Scattering by Nonspherical Particles: Theory, Measurements, and Applications, edited by: Mishchenko, M. I., Hovenier, J. W., and Travis, L. D.: Academic, San Diego, CA, 2000.

Schmid, B., Michalsky, J., Halthore, R., Beauharnois, M., Harrison, L., Livingston, J., Russell, P., Holben, B., Eck, T., and Smirnov, A.: Comparison of aerosol optical depth from four solar radiometers during the fall 1997 ARM intensive observation period, Geophys. Res. Lett., 26, 2725-2728, 1999.

Schmid, B., Ferrare, R., Flynn, C., Elleman, R., Covert, D., Strawa, A., Welton, E., Turner, D., Jonsson, H., Redemann, J., Eilers, J., Ricci, K., Hallar, A. G., Clayton, M., Michalsky, J., Smirnov, A., Holben, B., and Barnard, J.: How well do state-ofthe-art techniques measuring the vertical profile of tropospheric aerosol extinction compare?, J. Geophys. Res., 111, D05S07, doi:10.1029/2005JD005837, 2006. 
Shaw, G.E.: Sunphotometry, Bull. Am. Meteorol. Soc., 64, 4-10, 1983.

She, C. Y., Alvarez, R. J., Caldwell, L. M., and Krueger, D. A.: High-spectral-resolution Rayleigh-Mie lidar measurement of aerosol and atmospheric profiles, Opt. Lett., 17, 541-543, doi:10.1364/OL.17.000541, 1992.

Shipley, S. T., Tracy, D. H., Eloranta, E. W., Trauger, J. T., Sroga, J. T., Roesler, F. L., and Weinman, J. A.: High spectral resolution lidar to measure optical-scattering properties of atmospheric aerosols. 1: theory and instrumentation, Appl. Opt., 22, 37163724, 1983.

Shrivastava, M., Berg, L. K., Fast, J., Easter, R., Laskin, A., Chapman, E., Gustafson Jr., W. I., Liu, Y., and Berkowitz, C.: Modeling aerosols and their interactions with shallow cumuli during the 2007 CHAPS field study, J. Geophys. Res. Atmos., 118, 13431360, doi:10.1029/2012JD018218, 2013.

Smirnov, A., Holben, B. N., Eck, T. F., Dubovik, O., and Slutsker, I.: Cloud screening and quality control algorithms for the AERONET data base, Remote Sens. Environ., 73, 337-349, 2000.

Smirnov, A., Holben, B. N., Eck, T. F., Slutsker, I., Chatenet, B., and Pinker, R. T.: Diurnal variability of aerosol optical depth observed at AERONET (Aerosol Robotic Network) sites, Geophys. Res. Lett., 29, 2115, doi:10.1029/2002GL016305, 2002.

Smirnov, A., Holben, B. N., Dubovik, O., Frouin, R., Eck, T. F., and Slutsker, I.: Maritime component in aerosol optical models derived from Aerosol Robotic Network data, J. Geophys. Res., 108, 4033, doi:10.1029/2002JD002701, 2003.

Smirnov, A., Sayer, A. M., Holben, B. N., Hsu, N. C., Sakerin, S. M., Macke, A., Nelson, N. B., Courcoux, Y., Smyth, T. J., Croot, P., Quinn, P. K., Sciare, J., Gulev, S. K., Piketh, S., Losno, R., Kinne, S., and Radionov, V. F.: Effect of wind speed on aerosol optical depth over remote oceans, based on data from the Maritime Aerosol Network, Atmos. Meas. Tech., 5, 377-388, doi:10.5194/amt-5-377-2012, 2012.

Spinhirne, J. D., Rall, J. A. R., and Scott, V. S.: Compact Eye Safe Lidar Systems, Rev. Laser Eng., 23, 112-118, 1995.

Su, W., Schuster, G. L., Loeb, N. G., Rogers, R. R., Ferrare, R. A., Hostetler, C. A., Hair, J. W., and Obland, M. D.: Aerosol and cloud interaction observed from high spectral resolution lidar data, J. Geophys. Res., 113, D24202, doi:10.1029/2008JD010588, 2008.

Tackett, J. L. and Di Girolamo, L.: Enhanced aerosol backscatter adjacent to tropical trade wind clouds revealed by satellite-based lidar, Geophys. Res. Lett., 36, L14804, doi:10.1029/2009GL039264, 2009.

Twohy, C. H., Coakley, J. A., and Tahnk, W. R.: Effect of changes in relative humidity on aerosol scattering near clouds, J. Geophys. Res., 114, D05205, doi:10.1029/2008JD010991, 2009.
Várnai, T. and Marshak, A.: Global CALIPSO Observations of Aerosol Changes Near Clouds, IEEE, Geosci. Remote Sens. Lett., 8, 19-23, 2011.

Weigel, R., Borrmann, S., Kazil, J., Minikin, A., Stohl, A., Wilson, J. C., Reeves, J. M., Kunkel, D., de Reus, M., Frey, W., Lovejoy, E. R., Volk, C. M., Viciani, S., D’Amato, F., Schiller, C., Peter, T., Schlager, H., Cairo, F., Law, K. S., Shur, G. N., Belyaev, G. V., and Curtius, J.: In situ observations of new particle formation in the tropical upper troposphere: the role of clouds and the nucleation mechanism, Atmos. Chem. Phys., 11, 9983-10010, doi:10.5194/acp-11-9983-2011, 2011.

Welton, E. J., Campbell, J. R., Spinhirne, J. D., and Scott III, V. S.: Global monitoring of clouds and aerosols using a network of micro-pulse lidar systems, Proc. SPIE 4153, Lidar Remote Sensing for Industry and Environment Monitoring, 151 (13 February 2001), doi:10.1117/12.417040, 2001.

Wonaschuetz, A., Sorooshian, A., Ervens, B., Chuang, P. Y., Feingold, G., Murphy, S. M., deGouw, J., Warneke, C., and Jonsson, H. H.: Aerosol and gas re-distribution by shallow cumulus clouds: An investigation using airborne measurements, J. Geophys. Res., 117, D17202, doi:10.1029/2012JD018089, 2012.

Yang, W., Marshak, A., Varnai, T., and Liu, Z.: Effect of CALIPSO cloud-aerosol discrimination (CAD) confidence levels on observations of aerosol properties near clouds, Atmos. Res., 116, 134 141, doi:10.1016/j.atmosres.2012.03.013, 2012.

Zhang, J. and Reid, J. S.: MODIS aerosol product analysis for data assimilation: Assessment of over-ocean level 2 aerosol optical thickness retrievals, J. Geophys. Res., 111, D22207, doi:10.1029/2005JD006898, 2006.

Zhang, J., Reid, J. S., and Holben, B. N.: An analysis of potential cloud artifacts in MODIS over ocean aerosol optical thickness products, Geophys. Res. Lett., 32, L15803, doi:10.1029/2005GL023254, 2005.

Zhang, Y., Yu, H., Eck, T. F., Smirnov, A., Chin, M., Remer, L. A., Bian, H., Tan, Q., Levy, R., Holben, B. N., and Piazolla, S.: Aerosol daytime variations over North and South America derived from multiyear AERONET measurements, J. Geophys. Res., 117, D05211, doi:10.1029/2011JD017242, 2012.

Ziemba, L., Thornhill, K., Ferrare, R., Barrick, J., Beyersdorf, A., Chen, G., Crumeyrolle, S., Hair, J., Hostetler, C., Hudgins, C., Obland, M., Rogers, R., Scarino, A.,Winstead, E., and Anderson, B. E.: Airborne observations of aerosol extinction by in-situ and remote-sensing techniques: Evaluation of particle hygroscopicity, Geophys. Res. Lett., 40, 417-422, 2013. 